\title{
Sewage Sludge Disposal and Applications: Self-heating and Spontaneous Combustion of Compost Piles - Trace Metals Leaching in Volcanic Soils After Sewage Sludge Disposal
}

\author{
Mauricio Escudey 1,4 , Nelson Moraga2, \\ Carlos Zambra ${ }^{2}$ and Mónica Antilén ${ }^{3,4}$ \\ ${ }^{1}$ Universidad de Santiago de Chile, Facultad de Química y Biología, Departamento de \\ Química de los Materiales, Av. B. O'Higgins 3363, Santiago, \\ 2 Universidad de Santiago de Chile, Facultad de Ingeniería, Departamento de Ingeniería \\ Mecánica, Av. Bdo. O’Higgins 3330, \\ ${ }^{3}$ Pontificia Universidad Católica de Chile, Facultad de Química, Departamento de Química \\ Inorgánica, Vicuña Mackenna 4860, Santiago, \\ ${ }^{4}$ Center for the Development of Nanoscience and Nanotechnology, CEDENNA, Santiago,
}

Chile

\section{Introduction}

\subsection{Introduction}

Municipal solid waste landfills often develop scenarios of self heating, causing negative environmental impacts by odors, gas generation and smoke production. Self-ignition and resulting fires at landfills have been undesirable outcomes in compost piles worldwide. Field, laboratory and numerical studies have been considered trying to reproduce and understand the conditions under which self-heating and combustion may take place. Inside a compost pile built from solids obtained after municipal wastewater treatment, oxygen, methane, carbon monoxide and carbon dioxide concentrations and temperature change with time and in depth. Electric conductivity and $\mathrm{pH}$ show only slight changes. In field piles temperature increased with time, reaching a maximum of about $90^{\circ} \mathrm{C}$. While no spontaneous combustion was observed after six months in field experiments, in laboratory studies carried out in a closed bottom cylinder, self-ignition was observed and a maximum temperature of about $400^{\circ} \mathrm{C}$ was reached. Spontaneous combustion in compost piles is a chemical and biological process. Initially, the metabolism that allows microorganism growth causes temperature increase, but simultaneous oxidation of the organic matter also reinforces self-ignition at a lower value. When the temperature within the compost pile rises to about $87^{\circ} \mathrm{C}$, self-ignition follows mainly due to cellulose oxidation. Therefore, the conditions under which biomass increases must be studied. An important factor in the development of internal changes within the compost pile comes from atmospheric boundary conditions. General convection, radiation, rain rate and atmospheric humidity must be included as boundary atmospheric field conditions on the lateral and top surfaces. 
Local thermal equilibrium is assumed, which is a common assumption for porous media and packed particle beds, hence effective properties can describe the porous media. Coupled two-dimensional heat and oxygen diffusion in a compost pile of sewage sludge obtained from domestic wastewater treatment can be described using a transient, nonlinear mathematical model that includes the volumetric heat generation caused by the action of aerobic bacteria and by the oxidation of cellulose in a porous medium. Numerical simulations with the finite volume method allow the prediction of the pile's shape and size effects on the heat generated and on oxygen consumption. Transient temperature and oxygen concentration distributions within compost piles depend on their geometry. Heat (temperature) and mass transfer (oxygen) results indicate that pile height has an important effect on the heating. The volumetric heat generation caused by the action of aerobic bacteria and by the oxidation of cellulose in a porous medium must be incorporated as a function of the mean moisture by an essentially thermodynamic source term. Inside a compost pile made of solid residues obtained after municipal wastewater treatment, temperature changes, oxygen content and moisture can be measured in time and depth. The Richards equation is a standard, frequently used approach for modeling and describing water flow in variably saturated porous media such as soils and compost piles. The nonlinear mathematical model considers the Richards equation and a second mass transport equation for water content, and therefore the numerical simulations can describe the internal changes in heat, oxygen and moisture observed under field conditions. Therefore a model with three diffusion equations must be used to quantify the effects of moisture on temperature and oxygen concentration.

\subsection{Materials and methods. Experimental conditions}

For field and laboratory studies sewage sludge from "El Trebal", a domestic wastewater treatment plant located close to the city of Santiago, Chile, was used, where about $4 \mathrm{~m}^{3} / \mathrm{s}$ of wastewater are treated. In the field, four sewage sludge piles 1.5 and $2.5 \mathrm{~m}$ high, $6.2-7 \mathrm{~m}$ wide, and $8.5 \mathrm{~m}$ long, with a 3-D trapezoidal shape and a bulk density of $0.75 \mathrm{ton} / \mathrm{m}^{3}$ were prepared. Temperatures were measured using type $\mathrm{K}$ thermocouples $(\mathrm{Ni}-\mathrm{Cr})$ connected to an LA/AI-A8 Cole Parmer data acquisition system, and they were recorded every 5 min, during 80 to 120 hours. Measurements of humidity, $\mathrm{O}_{2}, \mathrm{CH}_{4}, \mathrm{CO}_{2}$, and $\mathrm{CO}$ were made twice a week; $\mathrm{pH}$, electric conductivity, and organic carbon were determined once a week. Water content was determined from the weight lost after heating $10 \mathrm{~g}$ of sample at $105^{\circ} \mathrm{C}$ for 24 hours, and electrical conductivity and $\mathrm{pH}$ were determined in a 1:2.5 solid:water ratio extract. Organic carbon content (expressed as \%OC), was determined by a wet oxidation method (Walkley \& Black, 1934) where the sample reacts with a mixture of $1 \mathrm{~N} \mathrm{~K}_{2} \mathrm{Cr}_{2} \mathrm{O}_{7}$ and concentrated $\mathrm{H}_{2} \mathrm{SO}_{4}$.

A Dräger Miniwarn equipment, equipped with an IR catalytic sensor for $\mathrm{CH}_{4}$ and electrochemical sensors for $\mathrm{O}_{2}, \mathrm{CO}_{2}$ and $\mathrm{CO}$, was used considering a $1.5 \mathrm{~L} / \mathrm{min}$ mass flow.

Field experiments were carried out for 20 weeks, a period during which wind speed and direction, relative humidity of air, and precipitation were also recorded.

In the laboratory a stainless steel cylinder $20 \mathrm{~cm}$ in diameter, $20 \mathrm{~cm}$ deep, and $2 \mathrm{~mm}$ wall thickness was used. The cylinder was externally insulated, with openings at depths of 0.0 , 1.0, 2.0, 2.5, 3.0, 7.0, 10.0 and $15.0 \mathrm{~cm}$ for thermocouples location. An adjustable electric heater was incorporated $2.5 \mathrm{~cm}$ over the cylinder, and experiments were carried out at different external temperatures. Sewage sludge was placed in the cylinder at the same bulk density observed in the field. 


\subsection{Mathematical modeling and numerical simulation of compost pile. Self-heating in compost pile, differential equations for temperature and oxygen concentration.}

Temperature and oxygen concentration are the important dependent variables for describing heat and mass transfer processes inside compost piles. Basic equations to build appropriate mathematical models, numerical solutions procedures, and the results obtained are presented in this section.

The mathematical model considers transient coupled two-dimensional heat and oxygen diffusion in porous media (Sidhu et al., 2007). The pile bottom is assumed to be adiabatic, as shown in Figure 1.

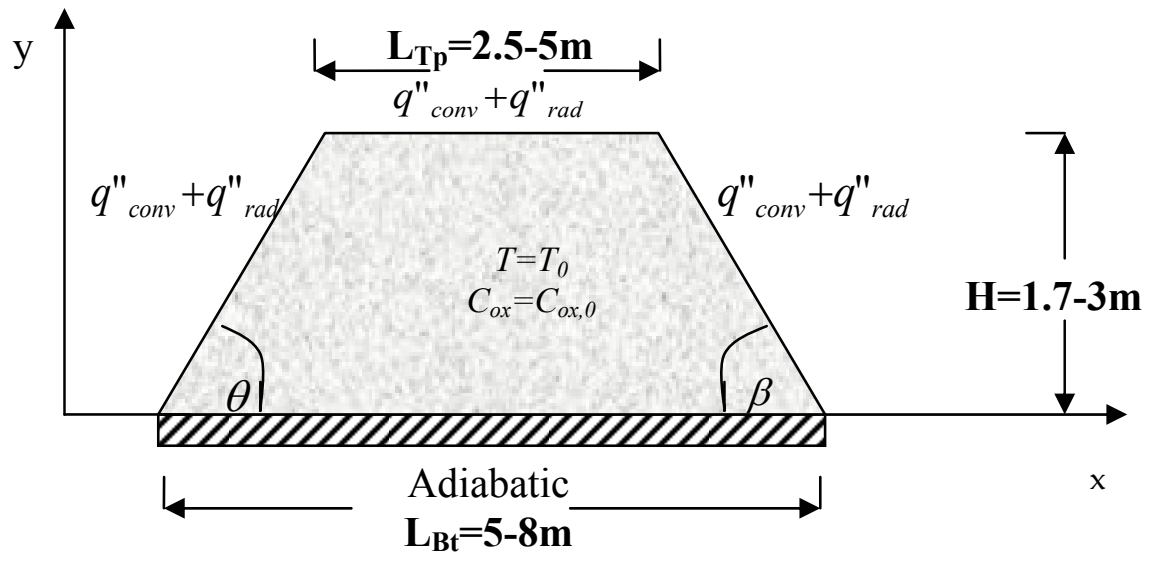

Fig. 1. Physical situation of the compost pile

Cellulosic oxidation and micro organism activity inside the pile are incorporated in the model by volumetric heat generation. For simplicity, local thermal equilibrium is assumed, which is a common assumption for porous medium and packed particle beds (Nield \& Bejan, 1992).

$$
\begin{gathered}
\frac{\partial(\rho C)_{e f f} T}{\partial t}=\nabla k_{e f f} \nabla T+Q_{c}(1-\varepsilon) A_{c} \rho_{c} C_{o x} \exp \left(\frac{-E_{C}}{R T}\right)+Q_{b}(1-\varepsilon) \rho_{b} \rho_{c}\left(\frac{A_{1} \exp \left(\frac{-E_{1}}{R T}\right)}{1+A_{2} \exp \left(\frac{-E_{2}}{R T}\right)}\right) \\
\varepsilon \frac{\partial C_{o x}}{\partial t}=\nabla D_{e f f} \nabla C_{o x}-(1-\varepsilon) A_{c} \rho_{c} C_{o x} \exp \left[\frac{-E_{c}}{R T}\right]
\end{gathered}
$$

In equations (1) and (2) $A_{c}$ is the pre-exponential factor for the oxidation of the cellulose and $E_{c}, E_{1}, E_{2}$, are the activation energy for cellulose, biomass growth and inhibition of biomass growth, respectively. Heat and mass transfer properties in the porous media are defined in terms of the pile's porosity $\varepsilon$,

$$
\begin{gathered}
k_{e f f}=\varepsilon k_{a i r}+(1-\varepsilon) k_{c} \\
(\rho C)_{e f f}=\varepsilon \rho_{a i r} C_{a i r}+(1-\varepsilon) \rho_{c} C_{c}
\end{gathered}
$$




$$
D_{\text {eff }}=\varepsilon D_{\text {air }, c}
$$

where $k_{\text {eff }}$ and $D_{\text {eff }}$ are the effective properties which are considered independent of temperature and concentration, and $C_{c}$ is the specific heat capacity of cellulose. The heat produced by the oxidation of the cellulosic material is represented by the second term on the right-hand side of the Equation (1). This term is expressed as a function of oxygen concentration and is responsible for the self-heating. The last term in Equation (1) represents heat generated due to biological activity within the pile, caused by microorganism growth. Oxygen content variation is included in Equation (2). Initially, oxygen content in the pile has the same concentration as in the external air. Micro-organisms growth followed by organic matter oxidation produces the oxygen depletion. These assumptions are incorporated in the second term on the right-hand side of the Equation (2).

Details in the formulation of the term representing the heat generated by the biomass have been given by Chen and Mitchell (Chen \& Mitchell, 1996) and some parameter values used in the mathematical model may be obtained from the literature (Sidhu et al., 2007; Escudey et al., 2008; Moraga et al., 2009).

\subsection{Temperature and oxygen concentration, initial and boundary conditions}

Initial temperature and oxygen and moisture distribution within the pile are assumed starting from the corresponding first experimental values available:

$$
T(x, y, 0)=T_{0} ; \quad C_{o x}(x, y, 0)=C_{o x, 0}
$$

Adiabatic and impermeable boundary conditions are considered at the pile's base

$$
y=0:\left.\quad \frac{\partial T}{\partial y}\right|_{y=0}=0 ;\left.\quad \frac{\partial C_{o x}}{\partial y}\right|_{y=0}=0
$$

Exchange with the surroundings at the outer pile surface should consider heat transfer caused by a combined action due to convection and radiation through impermeable walls:

$$
\begin{gathered}
y=H: \quad-\left.k_{\text {eff }} \frac{\partial T}{\partial y}\right|_{y=H}=q_{c o n v}+q^{\prime \prime}{ }_{\text {rad }} ;\left.D_{\text {eff }} \frac{\partial C_{o x}}{\partial y}\right|_{y=H}=0 \\
-\left.k_{\text {eff }} \frac{\partial T}{\partial n}\right|_{y=H}=q_{\text {conv }}^{\prime \prime}+q^{\prime \prime} \text { rad } ;\left.D_{\text {eff }} \frac{\partial C_{o x}}{\partial n}\right|_{y=H}=0 \\
q_{\text {conv }}^{\prime \prime}=h \cdot\left[T-T_{a}(t)\right]
\end{gathered}
$$

The heat transfer convective coefficient can be assumed to change with ambient air velocity v (Duffie \& Beckman, 1980):

$$
h=5.7+3.8 * v
$$

External thermal radiation incorporating incoming daily solar radiation and nocturnal heat losses can be calculated in terms of a function that periodically changes with time according to 


$$
q^{\prime \prime} \text { rad }=a \cdot \operatorname{sen}(w \cdot t)
$$

The pile dimensions indicate that an idealized two-dimensional domain is appropriate to assess the effects of pile geometry. Three cases were considered for the compost piles investigated: 1) symmetric trapezoidal; 2) asymmetric trapezoidal; 3) fifth polynomial contour.

\subsection{Numerical prediction using the Finite Volume Method.}

The system of equations that governs this problem (1-12) can be solved numerically using the finite volume method, Patankar (Patankar, 1991). Each one of the governing equations was written in the general form of the transport equation, with unsteady, diffusion and linearized source terms:

$$
\frac{\partial \phi}{\partial t}=\operatorname{div}(\Gamma \cdot \operatorname{grad} \phi)+S c+S p \cdot \phi
$$

First-order accuracy in time was used in the numerical scheme to account for the unsteady heat and mass terms:

$$
\frac{\partial \phi}{\partial t}=\frac{\phi^{t+\Delta t}-\phi^{t}}{\Delta t}
$$

The diffusion coefficient $(\Gamma)$ and source terms $(S c, S p)$ for each dependent variable $\phi$ are given in Table 1.

\begin{tabular}{|c|c|c|c|}
\hline$\phi$ & $\Gamma$ & $S_{C}$ & $S_{P}$ \\
\hline $\mathrm{T}$ & $k_{\text {eff }}$ & $\frac{T^{p}}{\Delta t}+Q_{c}(1-\varepsilon) \rho_{c} A_{c} C_{o x} \exp \left(\frac{-E_{C}}{R T}\right)+$ & $-\frac{1}{\Delta t}$ \\
& & $Q_{b}(1-\varepsilon) \rho_{b} \rho_{c}\left(\frac{A_{1} \exp \left(\frac{-E_{1}}{R T}\right)}{1+A_{2} \exp \left(\frac{-E_{2}}{R T}\right)}\right.$ & \\
\hline$C_{o x}$ & $D_{\text {eff }}$ & $\frac{C_{o x}^{p}}{\Delta t}$ & $-(1-\varepsilon) A_{c} \rho_{c} \exp \left[\frac{-E_{c}}{R T}\right]-\frac{1}{\Delta t}$ \\
\hline
\end{tabular}

Table 1. Diffusion coefficient and source terms for the mathematical model.

An original computer program written in Fortran, with a combination of the TDMA and the iterative Gauss-Seidel method (Patankar, 1991), was used to predict temperature and oxygen concentration inside the compost pile.

The pile geometry was discretized using three uniform grids: 100x100, 200x200 and 300x300 nodes in the $x$ and $y$ directions, respectively, to verify that the results obtained were not influenced by mesh size. Numerical simulations were carried out for four piles: 1.7, 1.8, 2.5 and $3.0 \mathrm{~m}$ height.

Temperature was noticed to increase initially smoothly with time while oxygen decreased slowly with time until sudden changes, caused by the cellulosic heat generation, were noticed for both temperature and oxygen concentration. 
Therefore, a strategy based on the use of dynamic time steps was implemented, with lower time steps when the unsteady terms were higher. The different values of the time steps used in the unsteady calculations were in the interval

$$
300 s \leq \Delta t \leq 3600 s
$$

The iterative procedure ended at each time step when the maximum difference between iteration for $\phi=T, C_{o x}$ satisfied, at each control volume, the convergence criteria

$$
\phi_{i, j}^{k+1}-\phi_{i, j}^{k} \leq 10^{-4}
$$

\subsection{Comparison between numerical predictions and experimental results.}

In order to validate the mathematical model and the numerical simulations a $2.5 \mathrm{~m}$ high, 8.5 $\mathrm{m}$ long and $7.0 \mathrm{~m}$ wide compost pile was built, with a 3D trapezoidal shape, with a $2.5 \mathrm{~m}$ wide top surface. Temperature was recorded using type $\mathrm{K}$ thermocouples (Ni-Cr) $0.1 \mathrm{~m}$ long and $0.0015 \mathrm{~m}$ in diameter, built with a type $\mathrm{G}$ junction and a silver end, provided with a 5-m long cable with flexible stainless steel coating. The thermocouples were connected to an LA/AI-A8 Cole Parmer data acquisition system coupled with a PC computer provided with the InstaTrend software programmed to collect temperatures every 10 minutes. Every week the values of the computer collected data were averaged and plotted. The temperature measurement points were located in the pile center ( $\mathrm{z}$ axis) at 2.1, 1.25 and $0.35 \mathrm{~m}$ depth. The pile was built with sewage sludge produced by a municipal wastewater treatment plant located in the city of Santiago, Chile (El Trebal) in a landfill belonging to the same plant. The sewage sludge was produced in July 2004 and was used to build the pile in the third week of February 2005.

The experimental and numerical data are compared in Figure 2 (Escudey et al., 2008). Data obtained from numerical calculations were plotted considering daily output at 12:00 a.m. The experimental and predicted data follow the same general trends. Near the surface $(0.35$ $\mathrm{m}$ depth) during the third week the main differences found were not greater than $3^{\circ} \mathrm{C}$. The best description of the experimental data was obtained at a depth of $2.1 \mathrm{~m}$.

\subsection{General analysis results for the temperature time evolution in a compost pile.}

A fundamental process in a compost pile is to achieve a higher enough temperature to cause the death of pathogenic micro-organisms together with the degradation of carbonaceous material. Field practice indicates that an adequate compost process may be achieved when the temperature inside the pile is between $313 \mathrm{~K}$ and $353 \mathrm{~K}$. Initially, the temperature inside the pile increases slowly from $293 \mathrm{~K}$ up to $353 \mathrm{~K}$ due to microorganism growth, as described by the last term on the right-hand side of Equation (1). As the temperature increases beyond $353 \mathrm{~K}$ the death of different microorganism colonies is followed by a sudden increase in cellulose oxidation, included as a volumetric heat generation in the second term on the right-hand side of Equation (1). Cellulose oxidation is accounted for in terms of the oxygen concentrations in the heat generation term of Equation (1) and of its counterpart term of oxygen depletion in the last term of the mass diffusion Equation (2). The sudden temperature increase is known as a thermal explosion.

The compost's physical properties change dramatically when the soil has undergone a thermal explosion and hence the compost material cannot be used as a soil fertilizer. Field 
control of such a sudden temperature increase is a very difficult task and thermal explosions often occur in practice, with loss of the compost material.

A first case of self-heating in a rectangular porous pile $2.5 \mathrm{~m}$ high $(\mathrm{H})$ and $5 \mathrm{~m}$ long $(\mathrm{L})$ was

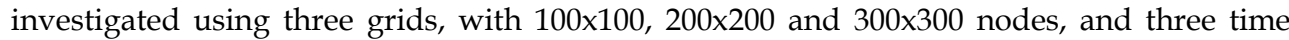
steps: $300 \mathrm{~s}, 600 \mathrm{~s}$ and $3600 \mathrm{~s}$. The temperature-time evolution was calculated at the three positions: f) $\mathrm{H} / 4, \mathrm{~L} / 4$; g) $\mathrm{H} / 2, \mathrm{~L} / 2$, and h) $3 \mathrm{H} / 4,3 \mathrm{~L} / 4$. The results of the time in days needed to cause self-ignition are shown in Table 2 for the three positions. The use of a time step of $600 \mathrm{~s}$ and a grid with 300x300 nodes allows to calculate self ignition times of 247, 246 and 250 days at the three vertical positions, respectively, regardless of the time and space discretizations.

\begin{tabular}{|c|c|c|c|c|}
\hline Grids & $\Delta t(\mathrm{~s})$ & $\mathrm{f}) \mathrm{H} / 4, \mathrm{~L} / 4$ & $\mathrm{~g}) \mathrm{H} / 2, \mathrm{~L} / 2$ & h) 3H/4, 3L/4 \\
\hline 100x100 & 3600 & 247 & 245 & 249 \\
\hline & 600 & 248 & 248 & 250 \\
\cline { 2 - 5 } & 300 & 244 & 241 & 246 \\
\hline \multirow{2}{*}{$200 \times 200$} & 3600 & 248 & 246 & 251 \\
\hline & 600 & 250 & 249 & 253 \\
\cline { 2 - 5 } & 300 & 246 & 244 & 249 \\
\hline \multirow{3}{*}{$300 \times 300$} & 3600 & 248 & 247 & 252 \\
\hline & 600 & 247 & 246 & 250 \\
\cline { 2 - 5 } & 300 & 247 & 246 & 250 \\
\hline
\end{tabular}

Table 2. Days before self-ignition at positions $\mathrm{f}$ ), g) and h) within the compost pile.

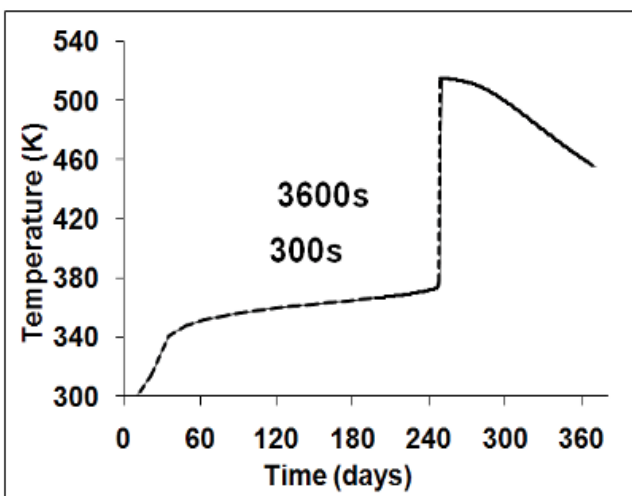

a)

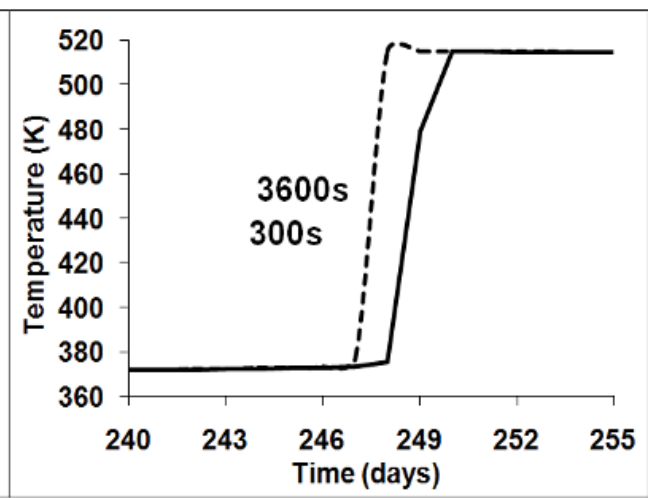

b)

Fig. 3. Temperature evolution in time calculated with two time steps, 300x300 mesh, at position $\mathrm{H} / 4, \mathrm{~L} / 4$, for a $2.5 \mathrm{~m}$ high pile, a) full time scale, b) during thermal explosion.

Figure 3 shows the time evolution results of temperature at the f) position: H/4, L/4, calculated with a grid of 300x300 nodes using two time steps: $300 \mathrm{~s}$ and $3600 \mathrm{~s}$. A typical heating curve depicting four stages is observed in Figure 3a. A first phase, lasting 35 days, 
where temperature increases from $293 \mathrm{~K}$ to $340 \mathrm{~K}$, is seen. The growth and activities caused by aerobic micro-organisms, included in the mathematical model by a volumetric heat generation, originated the initial pile heating. A second phase, from day 35 to day 246, with a very slow heating process in which temperature increases from $340 \mathrm{~K}$ to $370 \mathrm{~K}$, is originated initially by thermophilic micro-organisms whose number decreases progressively as temperature increases, followed by the cellulosic oxidation of the wood chips (used to increase the pile's mechanical strength), incorporated as the first heat generation term in the right-hand side of Eq. (1). Auto-ignition at H/4, L/4 occurs after 247 days, during the third stage, in which temperature increased suddenly in one day from 370 to $515 \mathrm{~K}$. A complex system of solid, liquid and gaseous fuels as a final result of cellulosic oxidation caused a volumetric heat generation that led to the self-ignition process. Temperature decreasing in time characterized the fourth and last stage, in which the fuel reserves at the location are becoming exhausted.

Figure 3b, a zoom view of Figure 3a for the time interval between days 240 and 255, shows that a time step reduction from $3600 \mathrm{~s}$ to $300 \mathrm{~s}$ allows a more accurate prediction (within 1 day) of the time needed to initiate the self-ignition in a $2.5 \mathrm{~m}$ high compost pile.

From the above analysis, a mesh with 300x300 nodes and a dynamic time step of $300 \mathrm{~s}$ during the self-ignition and $3600 \mathrm{~s}$ in the other stage are needed to solve the problem in an efficient way.

\subsection{Pile height effect on temperature and oxygen concentration}

In this section a critical pile height of $1.8 \mathrm{~m}$ for the thermal explosion to occur has been found. Heating curves at three different positions $(\mathrm{H} / 4, \mathrm{H} / 2$ and $3 \mathrm{H} / 4)$ located in the mid horizontal section of four rectangular piles ( $5 \mathrm{~m}$ wide) with $1.7,1.8,2.5$ and $3.0 \mathrm{~m}$ heights are shown in Figure 4. Temperature is observed to increase to $369 \mathrm{~K}$ in the $1.7 \mathrm{~m}$ high pile, at the $\mathrm{H} / 4$ and $\mathrm{H} / 2$ vertical locations, and to $353 \mathrm{~K}$ at the $3 \mathrm{H} / 4$ position after 728 days. A sudden temperature increase that took place at around 240 days for the 2.5 and $3.0 \mathrm{~m}$ high piles, and at 397 days (in H/4), 374 days (in H/2) and 409 days (in $3 \mathrm{H} / 4$ ) can be seen to characterize the initial time for the self-ignition process. Compost piles with heights greater than $1.7 \mathrm{~m}$ were found to initiate self-ignition in a time that is inversely proportional to pile height.

Changes in oxygen content with time, calculated inside the 1.7, 1.8, 2.5 and $3.0 \mathrm{~m}$ high compost piles, are described in Figure 5 at three vertical positions $(\mathrm{H} / 4, \mathrm{H} / 2$ and $3 \mathrm{H} / 4)$. As a result of the coupling between heat and mass transfer caused by the cellulose oxidation in both diffusion equations, sudden oxygen depletions are observed at the 1.8, 2.5 and $3.0 \mathrm{~m}$ pile height positions, occurring at the time when fast temperature increases were noticed. When pile height is $1.7 \mathrm{~m}$, oxygen concentration inside the pile remains almost constant during the 728 day period used in the analysis. Oxygen reduction to low levels in the domain, coupled with the high temperatures achieved in the same regions, destroys the aerobic thermophilic micro-organisms.

Table 3 summarizes the results obtained after the self-ignition analysis calculated from the time evolution of temperature and the oxygen concentration distributions inside the four rectangular piles of different heights. Temperature and oxygen distribution results show that when the pile volume to heat transfer external area ratio, $\mathrm{V} / \mathrm{A}$, is greater than or equal to 1.05 self-ignition occurs inside the pile. 

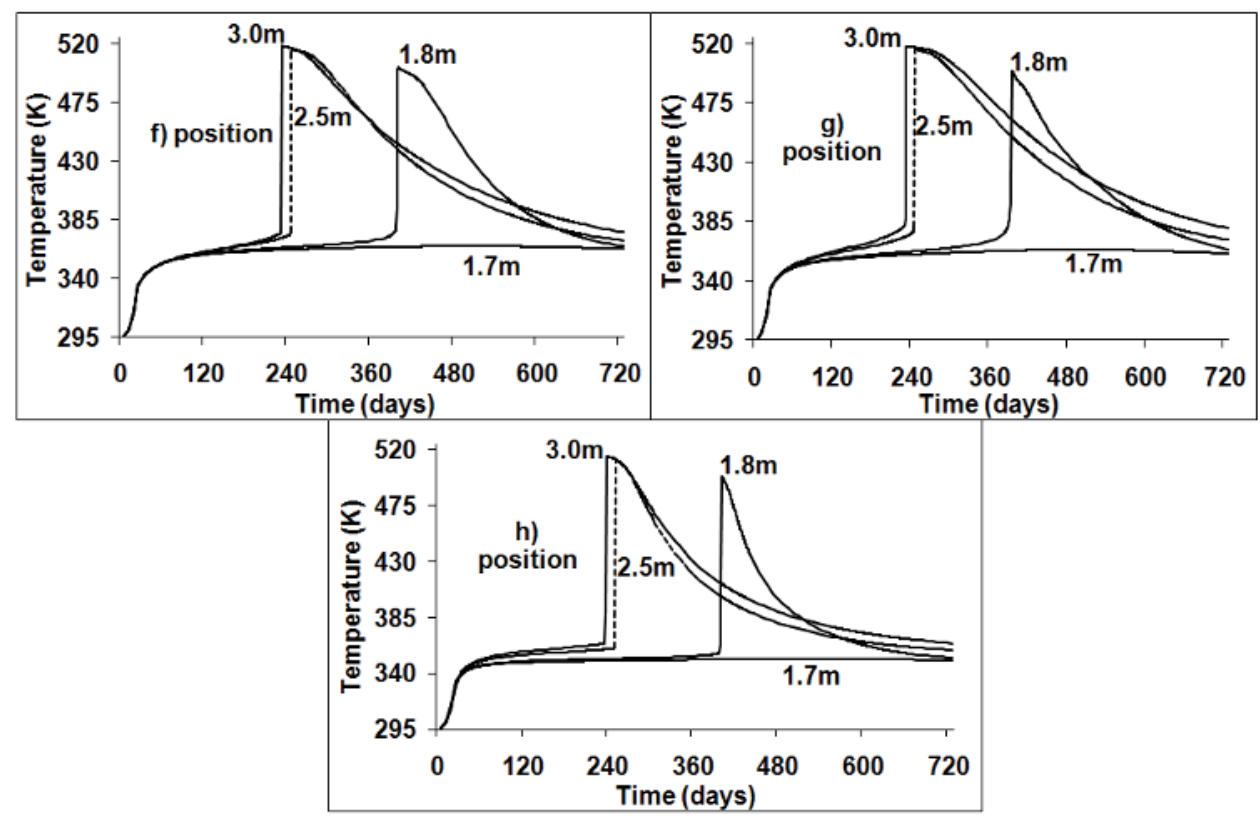

Fig. 4. Time evolution of temperature for four piles with different heights.
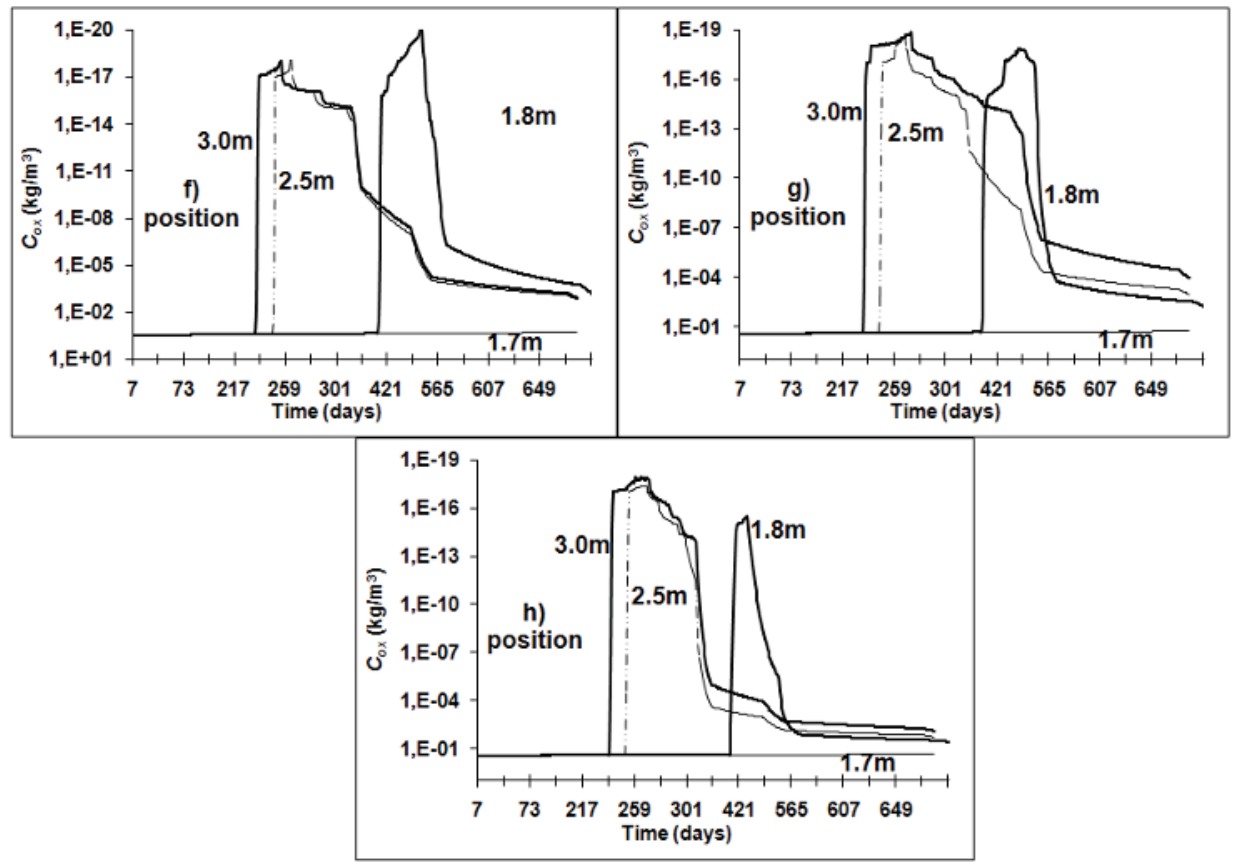

Fig. 5. Time evolution of oxygen concentrations for four piles with different heights. 


\begin{tabular}{|c|c|c|c|c|}
\hline Pile Height $(\mathrm{m})$ & Area $\left(\mathrm{m}^{2}\right)$ & Volume $\left(\mathrm{m}^{3}\right)$ & V/A Ratio $(\mathrm{m})$ & Self-Ignition \\
\hline 1.7 & 8.4 & 8.5 & 1.01 & no occur \\
\hline 1.8 & 8.6 & 9 & 1.05 & occur \\
\hline 2.5 & 10 & 12.5 & 1.25 & occur \\
\hline 3.0 & 11 & 15 & 1.36 & occur \\
\hline
\end{tabular}

Table 3. V/A ratio in four piles of different height.

Micro-organism and cellulosic heat generations inside the piles, calculated at a position located at mid section and $3 \mathrm{H} / 4$ for four different heights are presented in Figure 6 for the rectangular pile. A rapid initial growth followed by a fast fall in the microorganism volumetric heat generated can be noticed for the four pile heights studied. While cellulosic heat generation inside a $1.7 \mathrm{~m}$ pile height is seen to increase to a value that remains almost constant after 450 days, piles taller or equal to $1.8 \mathrm{~m}$ show a monotonous increment that is followed by a sudden increment, causing self-ignition. The heat generated by the biological activity of micro-organisms becomes equal to the heat generated by the cellulose oxidation after 102 days for the $1.7 \mathrm{~m}$ pile, 105 days for the $1.8 \mathrm{~m}, 84$ days for the $2.5 \mathrm{~m}$, and 77 days for the $3.0 \mathrm{~m}$ high piles. In the $1.7 \mathrm{~m}$ high pile, after 100 days, cellulosic oxidation keeps the temperatures for all time simulation while the oxygen consumption increases until day 500 and then decreases. Maximum heat generation values for the cellulose oxidations are $2.4 \times 10^{5}$ $\left(\mathrm{W} / \mathrm{m}^{3}\right), 5.7 \times 10^{5}\left(\mathrm{~W} / \mathrm{m}^{3}\right)$ and $6.4 \times 10^{5}\left(\mathrm{~W} / \mathrm{m}^{3}\right)$ for the $1.8 \mathrm{~m}, 2.5 \mathrm{~m}$ and $3.0 \mathrm{~m}$ high piles, respectively.

In the water treatment industry the piles are about $1.5 \mathrm{~m}$ high and $120 \mathrm{~m}$ long. Numerical results verified by experimental observations show that temperature increase in the pile is a function of the volume. Therefore, pile height must be considered a very important factor in thermal explosions. When the initial oxygen content within the pile is at adequate concentrations, microorganism and temperature increases are seen. This occurs until the temperature reaches $353 \mathrm{~K}$, when two phenomena occur: death of the micro-organisms and cellulosic oxidation. The numerical results shown in Figures 6-8 reproduce the biochemical processes described above, resulting in sudden changes in both oxygen and temperature in piles $1.8 \mathrm{~m}$ high or higher.

\subsection{Compost pile geometric effects.}

Heat and mass transfer characteristics are described in Figures 9-11 in terms of temperature and oxygen concentration distribution at four different times in the neighborhood of the self-ignition time. These results were obtained by numerical simulations using the proposed model, equations (1-12). Figure 9 shows the temperaturetime evolution and oxygen concentration distributions for a symmetrical trapezoidal pile $3 \mathrm{~m}$ high and $8 \mathrm{~m}$ at the base, with lateral walls inclined at $45^{\circ}$. A maximum temperature of $440 \mathrm{~K}$ was reached after 208 days in the pile's lower-central section, which increases to $519 \mathrm{~K}$ on day 216 and is located in the central region at H/3. Temperatures higher than $500 \mathrm{~K}$ were measured in the central pile region for 60 days. Oxygen content inside the pile is observed to tend to zero in the lower central section of the pile from 216 to 252 days. Almost the whole pile was seen to be undergoing self-ignition on day 225 except in the regions close to the lateral and top areas. 


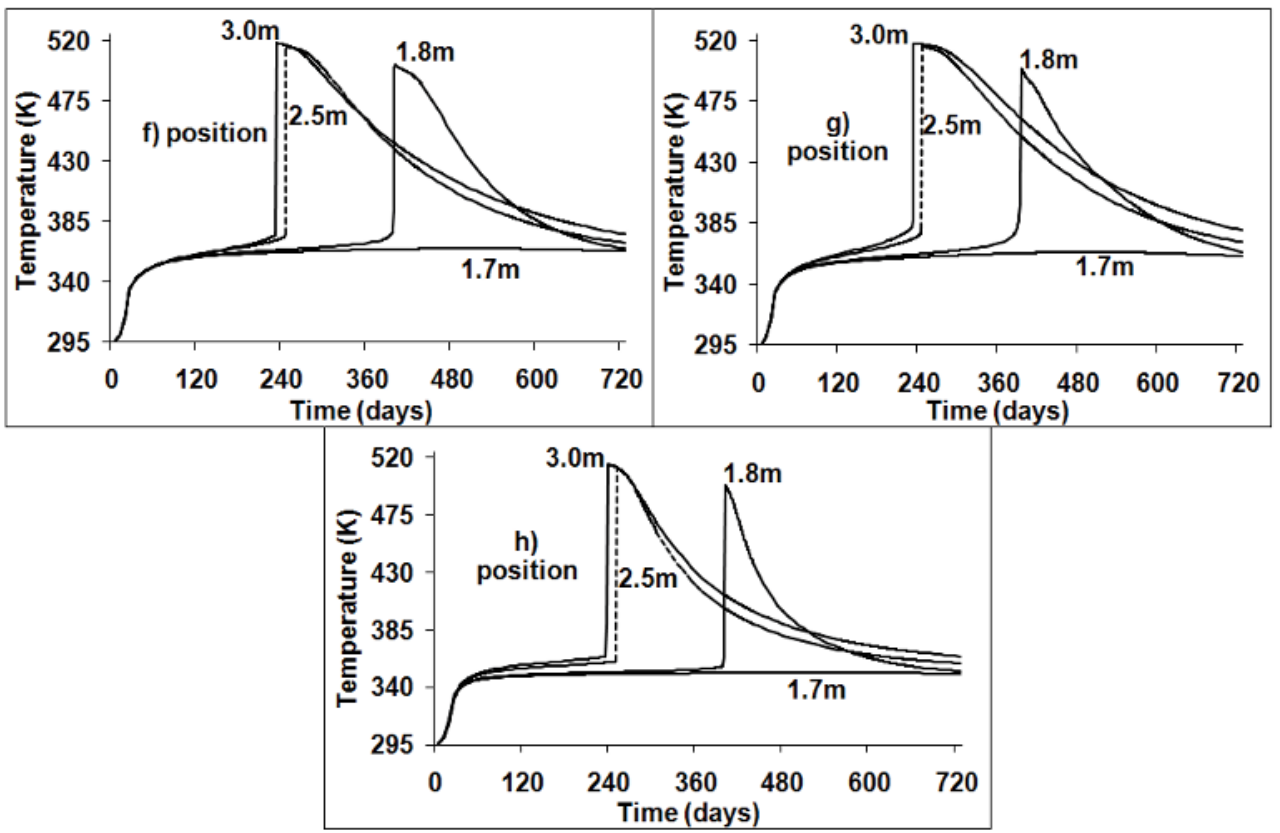

Fig. 6. Time evolution of temperature for four piles with different heights.

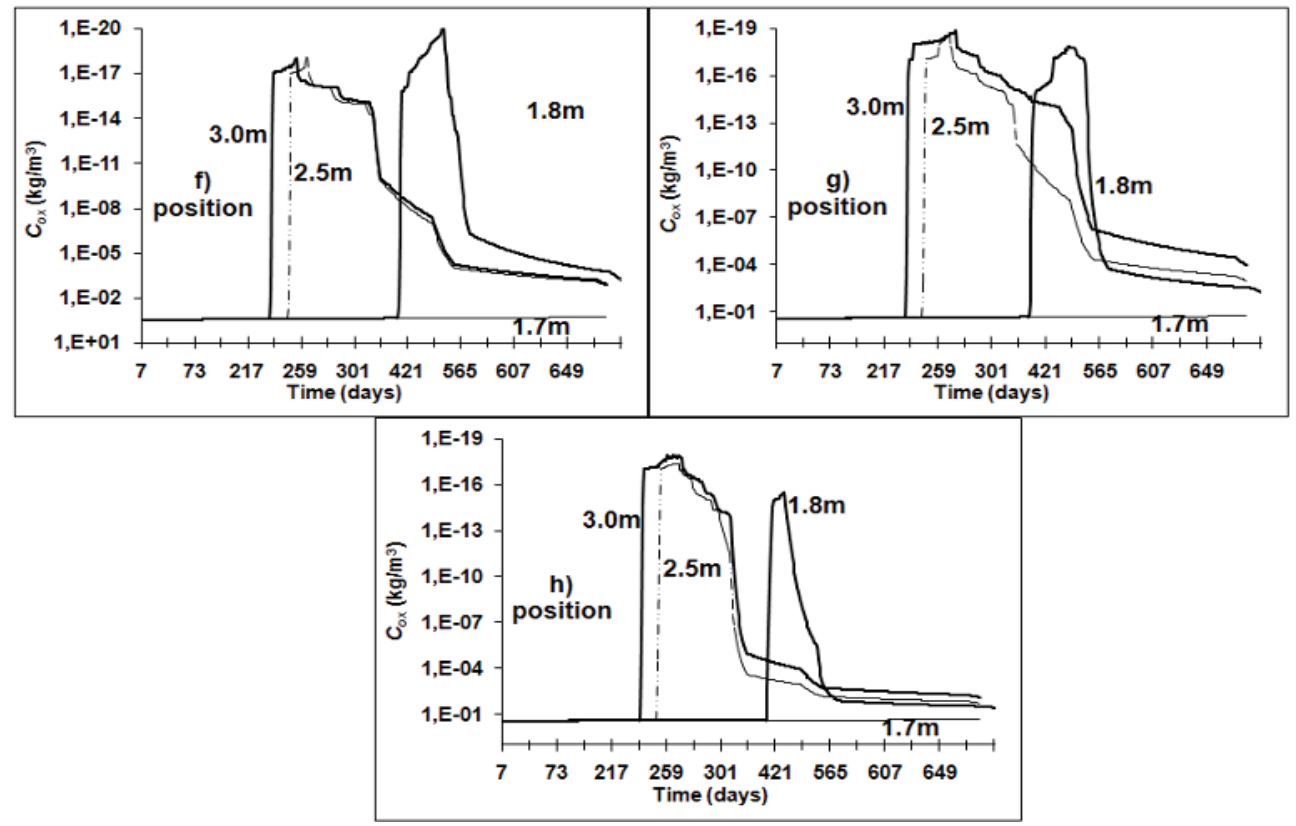

Fig 7. Time evolution of oxygen concentration for four piles with different heights. 


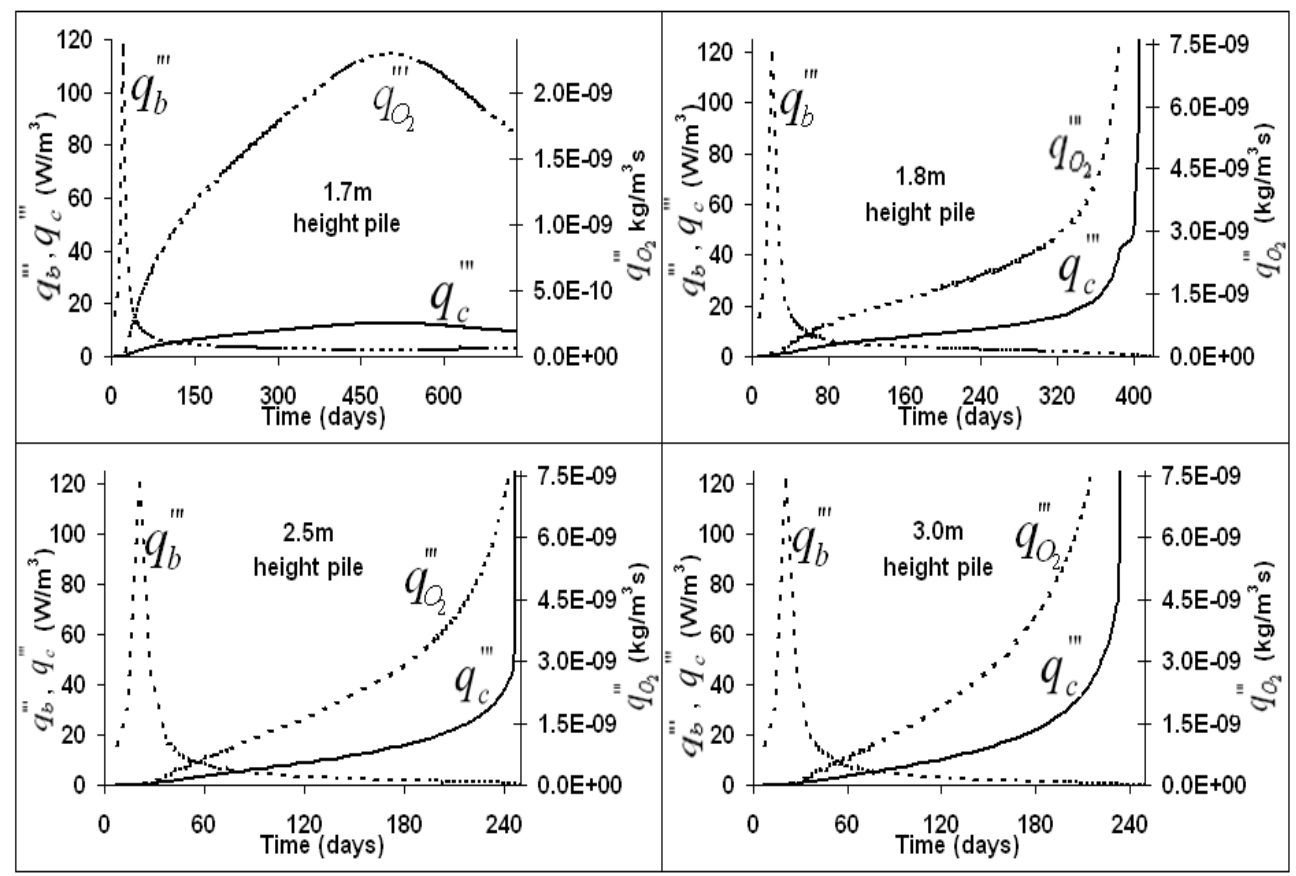

Fig. 8. Time evolution of energy and oxygen consumption for four piles with different heights.

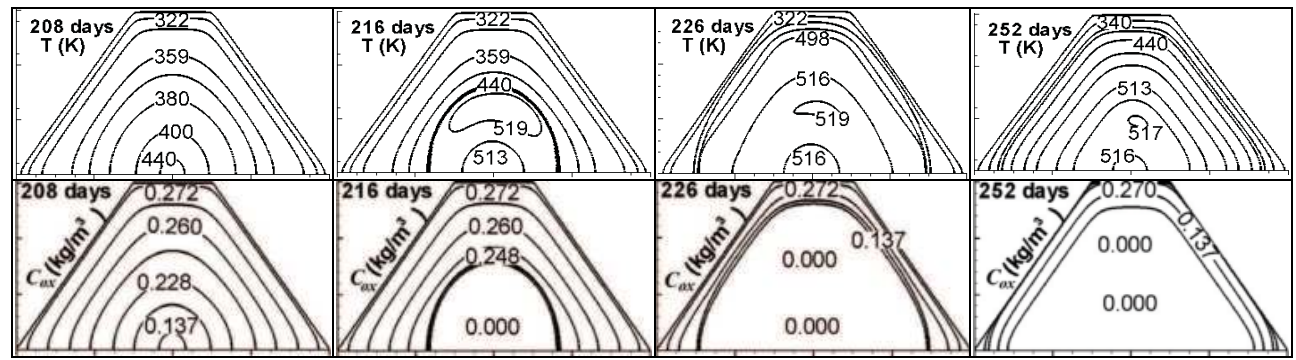

Fig. 9. Distribution of temperature and oxygen concentration within a compost pile, trapezoidal geometry.

Heat and mass transfer inside a non-symmetric trapezoidal sludge pile with an $8 \times 8 \mathrm{~m}$ base and lateral walls inclined at angles of $\theta=56.3^{\circ}$ and $\beta=33.7^{\circ}$ caused by chemical and biological reactions, are described in Figure 10 in terms of temperature and oxygen distribution. Self-ignition started on day 215, when a maximum temperature of $513 \mathrm{~K}$ was achieved. A narrow region with high temperature gradients can be observed in the lower central region of the pile on day 217. At this time the self-ignition front is closer to the bigger lateral wall (with $\beta=33.7^{\circ}$ ), and therefore smoke production can be expected to begin there. During self ignition the zone with maximum temperature, between 516 and $519 \mathrm{~K}$, reached between days 217 and 253 is closer to the shorter lateral wall. 


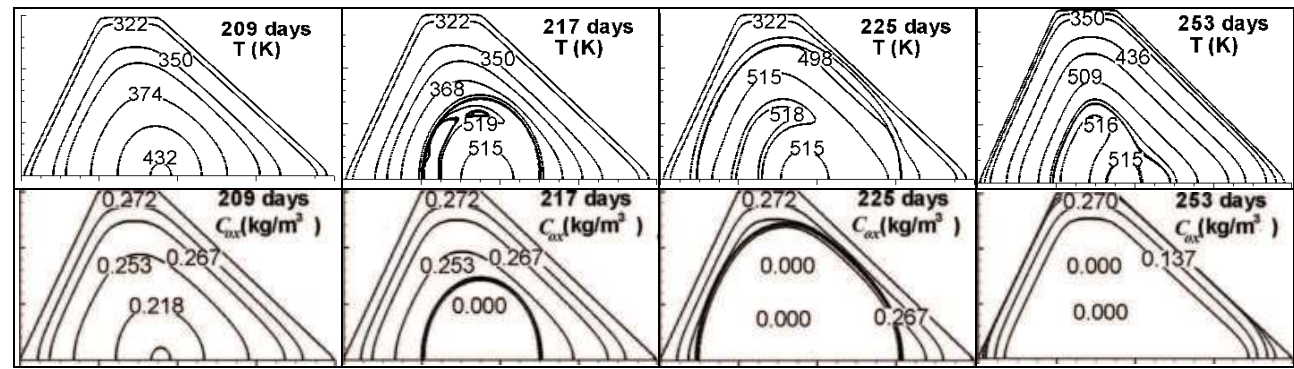

Fig. 10. Distribution of temperature and oxygen concentration within a compost pile, asymmetric geometry.

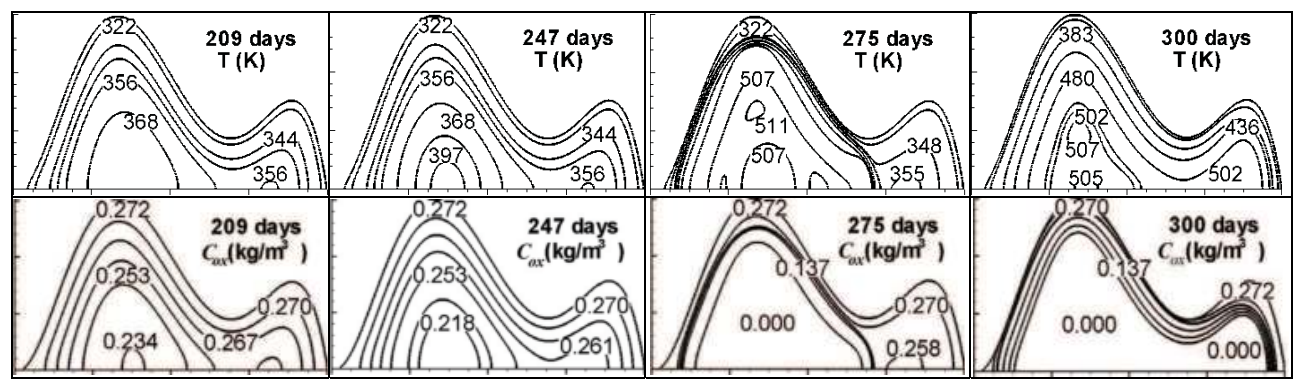

Fig. 11. Distribution of temperature and oxygen concentration within a compost pile, polynomial geometry.

Time evolution of temperature and oxygen concentration distributions at 209, 247, 275 and 300 days for an asymmetrical compost pile with two different height bumps, with maximum heights of $3 \mathrm{~m}$ and $8 \mathrm{~m}$ at the base, are shown in Figure 11. Self-ignition occurs near the base of the taller region on day 258, with a maximum temperature of $493 \mathrm{~K}$ that propagated towards the central zone of the taller region and then migrated towards the pile section with lower height $(1.5 \mathrm{~m})$, where a maximum temperature of $502 \mathrm{~K}$ can be noticed on day 300 . The self-combustion zone can be easily detected as the region in which the oxygen content is zero and on day 300 it can be seen to extend from the pile's base to a region close to the external walls.

\subsection{Flow in compost pile as an unsaturated porous medium}

The Richards equation (RE) (Richards, 1931) is a standard, frequently used approach for modeling and describing flow in variably saturated porous media. RE is obtained by combining Darcy-Buckingham's law with the mass conservation or continuity equation, under the assumption that the air phase remains at constant (atmospheric) pressure and the water phase is incompressible. Using one dimensional flow in a vertical direction, $y$, as an example, the following equations depict Darcy's and continuity equation, respectively.

$$
q_{D}=-k_{h} \frac{\partial \Psi}{\partial y}=-k_{h} \frac{\partial(\psi+y)}{\partial y}=-k_{h}\left(\frac{\partial \psi}{\partial y}+1\right)
$$




$$
\frac{\partial \theta}{\partial t}=-\frac{\partial q_{D}}{\partial y} \pm S
$$

where $q_{D}$ is the flux density $(\mathrm{m} / \mathrm{s}), k_{h}$ is the hydraulic conductivity $(\mathrm{m}), \Psi$ is the head equivalent of hydraulic potential $(\mathrm{m})$, is the head pressure $(\mathrm{m}), \theta$ is the volumetric water content $\left(\mathrm{m}^{3} / \mathrm{m}^{3}\right), y$ is the vertical coordinate, $t$ is time (s) and $S$ is the source term. Substitution of Equation (17) into (18) gives the mixed formulation of RE:

$$
\frac{\partial \theta}{\partial t}=\frac{\partial}{\partial y}\left[k_{h}\left(\frac{\partial \psi}{\partial y}+1\right)\right] \pm S
$$

Introducing a new term, $D(\theta)$ into (19) gives the soil moisture based form of $R E$. $D(\theta)$ is the ratio of the hydraulic conductivity, and the differential water capacity is therefore defined as

$$
D_{(\theta)}=\frac{k_{h}}{\frac{\partial \theta}{\partial \psi}}=k_{h} \frac{\partial \psi}{\partial \theta}
$$

$\mathrm{D}(\theta)$ is a function of moisture content. This dependence is obtained from field tests.

Combining Equations (19) and (20) gives the $\theta$ - based form of RE:

$$
\frac{\partial \theta}{\partial t}=\frac{\partial}{\partial y}\left(D_{(\theta)} \frac{\partial \theta}{\partial y}\right)+\frac{\partial k_{h}}{\partial y} \pm S
$$
If the gravitational and the source term effects are neglected, the $\frac{\partial k_{h}}{\partial y}$ the and $S$ terms in
Equation (21) are equal to zero.

$$
\frac{\partial \theta}{\partial t}=\nabla D_{(\theta)} \nabla \theta,
$$

The volumetric water content is the quotient between water volume and total sample volume, so it has no units and its values are between 0 and 1 .

The 1D mass transfer of water in soil solution of Equation (22) for volumetric water content diffusion, testing the effects on the thermal properties caused by moisture in porous media, has been reported by Serrano (Serrano, 2004). This diffusivity coefficient of water in a compost pile is calculated by a nonlinear equation:

$$
D_{(\theta)}=\vartheta_{1} e^{\lambda(\theta)^{\alpha}}-\vartheta_{2}
$$

The constants $\vartheta_{1}, \vartheta_{2}, \lambda$ and $\alpha$ can be obtained by experimental field tests (Serrano, 2004). Equations (22) and (23) may be used when the specific hydraulic properties of the compost pile are not available.

The effects of the vaporization of water on the internal energy may be calculated by incorporating the third term of the right hand side of Equation (17):

$$
-L_{v} \rho_{v a} q(\theta) X_{v}
$$


where $L_{v}$ is the vaporization enthalpy, $\rho_{v, a}$ is the water vapor density, $q(\theta)$ is the mass water flux, and $X_{v}$ is the vapor quality.

\subsection{Humidity, initial and boundary conditions.}

Moisture distributions within the pile are assumed starting from the corresponding first experimental values available:

$$
\theta(x, y, 0)=\theta_{0}
$$

A constant volumetric concentration was imposed at the pile base:

$$
\left.\frac{\partial \theta}{\partial y}\right|_{y=0}=0.6
$$

Heat transfer to the environment when the liquid - vapor phase change takes place was calculated with the equation

$$
q "_{W}=h_{W} L_{v}\left(\theta_{W, m l}-\theta_{W, \text { air }, e x}\right) \rho_{W, v a},
$$

where $\theta_{w, m l}$ is the water content in the fluid adjacent to the surface, $\theta_{w, a i r, e x}$ is the water content in the outside air, $\rho_{w, v a}$ is the water vapor density on the surface, and $h_{w}$ is the convective mass transfer coefficient. In order to improve the accuracy of the approximation, $q^{\prime \prime}{ }_{w}$ were written in the form of a three-point formula (Ozisik, 1994). On the pile's surface $h_{w}$ and $\theta_{w, a i r, e x}$ are affected by the distribution coefficient, $K$, at the interface between the fluid and the solid. Figure 12 shows three concentration points at the interface used for calculating the mass transfer and convective mass transfer at the solid surface using the equilibrium distribution coefficient (Geankoplis, 1993).
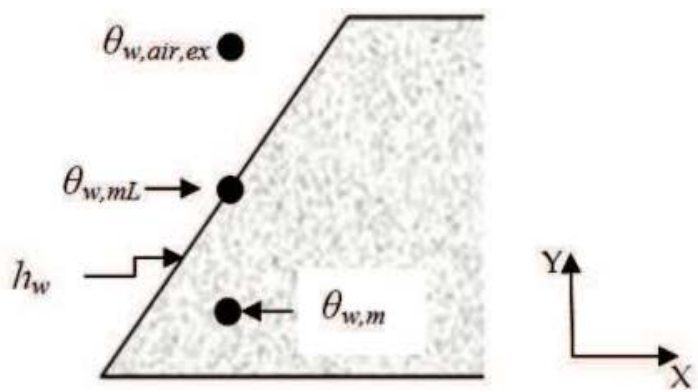

Fig. 12. Source term values for thermodynamic equilibrium

$$
K=\frac{\theta_{w, m l}}{\theta_{w, m}} .
$$

In Equation (28) $\theta_{w, m}$ is the water content in the solid adjacent to the surface. Substituting Equation (28) in Equation (27) we get:

$$
q_{w}^{\prime \prime}=h_{W} K L_{V}\left(\theta_{W, m}-\frac{\theta_{W, \text { air }, \text { ex }}}{K}\right) \rho_{W, v a}
$$


The equation for $h_{w}$ values is obtained as follows (Kaya et al., 2006):

$h_{W}=h\left(\frac{D_{w, \text { air }} L e^{g}}{k_{\text {eff }}}\right) ; \quad g=1 / 3 ; \quad L e=k /\left(\rho \cdot C_{p}\right) \cdot D_{w, \text { air }}($ Lewis number $)$

Water content at the air-compost interface is calculated assuming an ideal gas mixture and molar concentration depending on partial vapor pressure and temperature at the interface

$$
\theta_{w, m l}=\frac{p_{v a} * 18}{R T \rho_{w, v a}}
$$

The vapor pressure is obtained from the relative humidity, $\% H$, as follows:

$$
p_{v a}=\% H \cdot p_{v a}^{*},
$$

where $p_{v a}^{*}$ is the saturated vapor pressure. Rain effects as boundary condition were incorporated through Equation (20), considering a relative humidity equal to 1 at the surface of the compost pile.

Convective boundary conditions for water content are introduced through equations (33) and (34).

$$
\begin{gathered}
\left.D_{W, \text { air }} \frac{\partial \theta}{\partial y}\right|_{y=H}=h_{W} K\left(\theta_{W, m}-\frac{\theta_{W, \text { air }, \text { ext }}}{K}\right) \\
\left.D_{W, \text { air }} \frac{\partial \theta}{\partial y}\right|_{y=H}=h_{W} K\left(\theta_{W, m}-\frac{\theta_{W, \text { air }, \text { ext }}}{K}\right)
\end{gathered}
$$

\subsection{Experimental and numerical results for humidity.}

Unsteady water diffusion inside the sewage sludge was investigated by physical experiments and finite volume simulations, based on the mathematical model described by equations (1-5). A compost pile $2.5 \mathrm{~m}$ high, $8.5 \mathrm{~m}$ long and $7.0 \mathrm{~m}$ wide was built, with a 3D trapezoidal shape and a $2.5 \mathrm{~m}$ wide top surface.

Figure 13 shows the values measured for rain, wind velocity, and relative humidity at $E l$ Trebal. In the southern hemisphere February-March correspond to the summer season and April-June correspond to the fall season, where ambient temperature decreases from 293 to $282 \mathrm{~K}$. In this period wind speed drops from about 4.5 to $2 \mathrm{~m} / \mathrm{s}$ and the relative humidity of the air increases from 54 to 84 percent. The frequency and amount of rain also increase in this period, with maximum values of $40 \mathrm{~mm}$ in one continuous rainfall period.

The values measured in the field and those calculated by the FVM (Finite Volume Method) for water content, oxygen concentration, and temperature for each point of measurement are shown in Figure 12. Water content from 0.45 to 0.6 represents optimal conditions for biomass growth. In the field experiment those limiting values were exceeded.

The water content in Figure 14.a is affected by the atmospheric conditions of relative humidity and precipitation, and this is clearly seen at a height of $2 \mathrm{~m}$. Further increases in water content within the compost pile take place when both the relative humidity and precipitation (frequency and quantity) increase. Water content at $0.5 \mathrm{~m}$ is less affected by the 

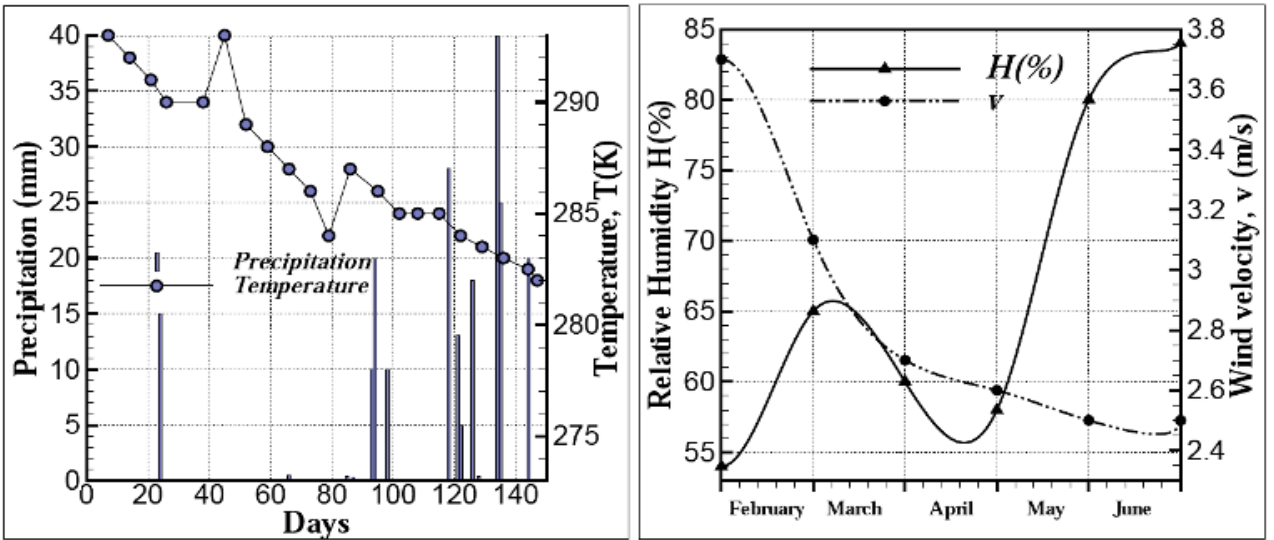

Fig. 13. Precipitation, temperature, relative humidity and wind in El Trebal.
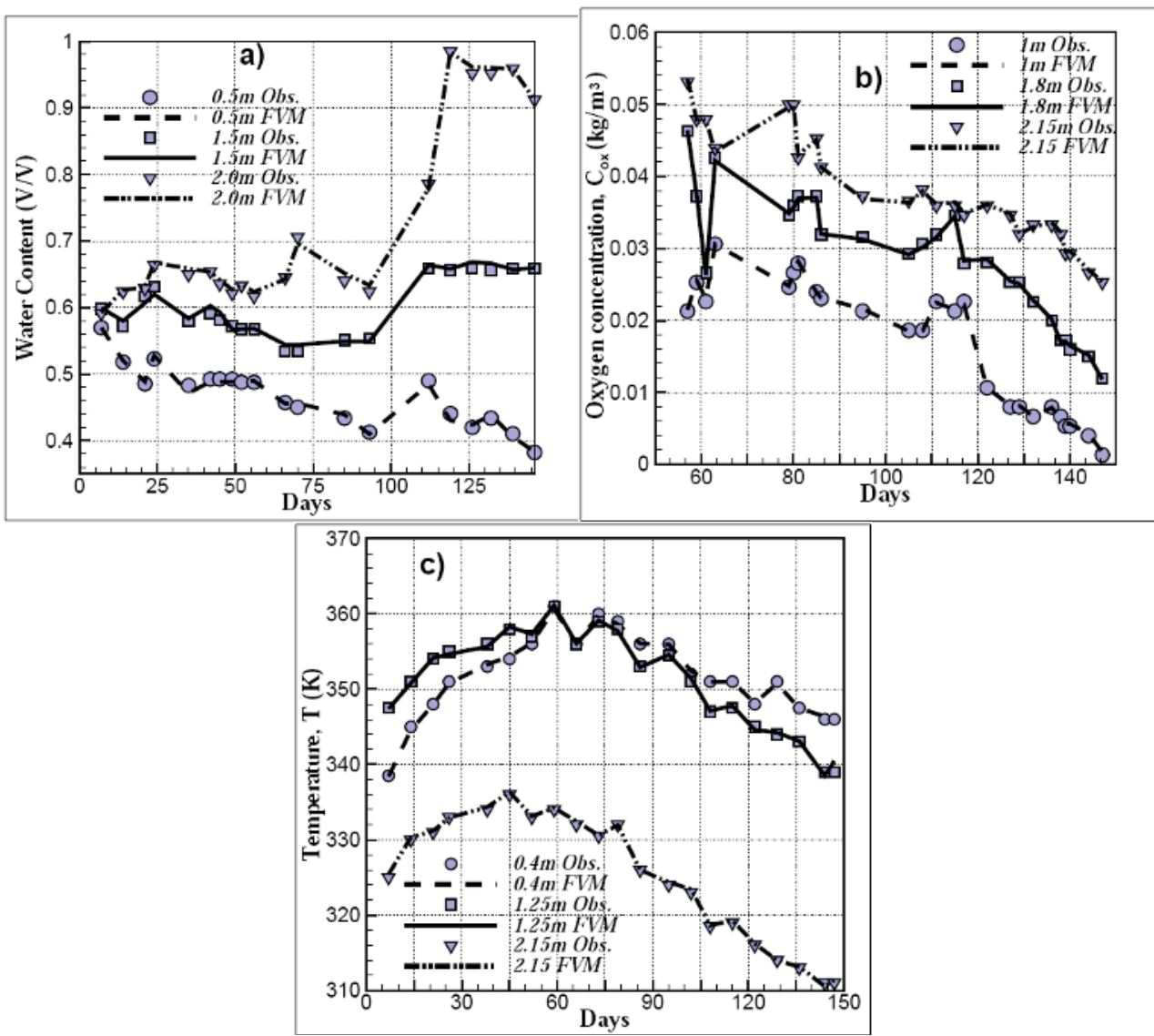

Fig. 14. Water content, oxygen concentration, and temperature observed in the field and calculated with the Finite Volume Methods (FVM) at three heights. 
conditions outside the compost pile; at this height the water content is mainly affected by flow into the soil at the pile's base.

In Figure 14.b the oxygen concentration has a tendency to decrease with time. After 115 days the frequency and quantity of rain increase, producing further declines in oxygen concentration because the water displaces the oxygen in the pores. No self ignition conditions were reached in the field during the 21 weeks of the experiment, as shown in Figure 14.c. During the first weeks, temperature in the sewage sludge piles increased up to about $363 \mathrm{~K}$, and it was higher at the first two heights measured within the compost pile. As expected, when temperature in the pile increases, oxygen $\left(C_{o x}\right)$ and water content $(\theta)$ decrease. Self heating in the compost pile is clearly affected by atmospheric temperature, solar radiation, wind, relative humidity, and precipitation conditions, however further declines in the values are seen after 85 days, caused by the increase in relative humidity and precipitation.

The environment in which the microorganism and chemical reactions occur is altered because of the changes in the moisture and oxygen concentrations, so biological metabolism and chemical reactions decrease, and therefore the temperature within the compost pile also drops. Maximum errors of $0.5 \mathrm{~K}$ for temperature and $0.0005 \mathrm{~m}^{3} / \mathrm{m}^{3}$ and $\mathrm{kg} / \mathrm{m}^{3}$ for water content and oxygen concentration between experimental and numerical results were found.

\subsection{Conclusions}

Numerical simulations indicate that self-combustion does not take place when the piles are less than $1.8 \mathrm{~m}$ high, as has been observed in practice. The heat transfer results show that the heating process is initiated by the volumetric heat generation by micro-organisms, and the thermal explosion is caused by cellulose oxidation when the volume to area ratio exceeds 1 . The time required to initiate self combustion is inversely proportional to pile height. The internal distribution of temperature and oxygen concentration depends on the geometry of the compost pile. A mathematical model that considers moisture, oxygen and temperature and their corresponding boundary conditions for modeling the compost processes in static compost pile has been proposed.

Numerical simulation with a mesh of $300 \times 300$ nodes and dynamic time states between 300 and $3600 \mathrm{~s}$ can be used with the Finite Volume Method to predict temperature, oxygen concentration, and humidity within the compost pile.

\section{Trace metal leaching in volcanic soils after sewage sludge disposal.}

\subsection{Introduction}

Sewage sludge is the inevitable end product of municipal wastewater treatment processes worldwide. As the wastewater is purified, the impurities removed from the water stream are concentrated. The sludge stream thus contains many chemical and microbiological constituents usually in concentrated forms that may become potential sources of pollutants when the material is released. No matter how many treatment steps it undergoes, at the end, the sludge and/or its derivatives (such as sludge ash) require ultimate disposal, for which the sewage sludge may be land applied, land filled, incinerated, or ocean dumped. There is no entirely satisfactory solution and all of the currently employed disposal options have serious drawbacks. Land application however is by far the most commonly used method around the world. Approximately six million dry tons of sewage sludge are produced 
annually in the United States (Bastian, 1997). A recent report showed that the annual production of sewage sludge in member countries of the European Union may reach as much as $8 \times 10^{6}$ tons (Bonnin, 2001). Significant amounts of sewage sludge produced in the United States and the western European nations have been applied on land. Depending on the regions, 24 to $89 \%$ of the sludge produced in the U.S. (Bastian, 1997)has been applied on land. Bonnin (Bonnin, 2001) reported that $65 \%$ of the sewage sludge in France was land applied. The situations in other parts of the world are expected to be similar.

As the residue of municipal wastewater treatment, sewage sludge represents the aggregation of organic matter, pathogens, trace elements, toxic organic chemicals, essential plant nutrients, and dissolved minerals originally dispersed in the wastewater that are captured and transformed by the wastewater treatment processes. Properly managed, the potential pollutants are assimilated via the biochemical cycling processes of the receiving soils in the land application. The practice provides soils with organic materials and offers the possibility of recycling plant nutrients, which in turn improve the fertility (Walter \& Cuevas, 1999) and physico-chemical properties of agricultural soils (Illera et al., 2006). If not appropriately controlled, the potential pollutants released through land application may degrade the quality of downstream water bodies, be transferred through the food chain to harm the consumers of harvests, and drastically alter the physical and chemical properties of the receiving soils. It is imperative for mass input to provide adequate amounts of substances that are useful for plant development and for pollutant inputs to be controlled to avert detrimental public health and environmental effects. Major countries such as the United States, the European Union (www.europa.eu.int/comm/environment/sludge) have enacted regulations or issued guidelines that limit the disposal options for a variety of reasons. As already mentioned, municipal sewage sludge contains organic matter, essential plant nutrients, and dissolved minerals, and has buffering capacity (Eriksson, 1998; Zhang et al., 2002a, 2002b; Escudey el al., 2004a, 2004b; Pasquini \& Alexander, 2004). When landapplied, they may replenish the depleting nutrient reservoirs in these soils under cultivation, allowing the recovery of soil organic matter lost either during a forest fire or in degradation processes due to adverse environmental conditions and unsuitable agricultural practices (Margherita el al., 2006), but they may also involve the input of variable quantities of heavy metals.

In the sewage sludge used, the levels of heavy metals follow the sequence $\mathrm{Zn}>\mathrm{Mn}>\mathrm{Cu}>\mathrm{Cr}>\mathrm{Pb}>\mathrm{Ni}>\mathrm{Mo}>\mathrm{Cd}$ (from $1780 \mathrm{mg} / \mathrm{kg}$ for $\mathrm{Zn}$ down to $5 \mathrm{mg} / \mathrm{kg}$ for $\mathrm{Cd}$ ), with land application ass one of the primary options under consideration at this time. In this sense the evaluation of the total metal content in soils or sewage sludge is useful for a global index of contamination, but it does not provide information about pollutant chemical fractions. On the other hand, it has been widely recognized through biochemical and toxicological studies that the environmental impact of heavy metal pollution can be related to soluble and exchangeable fractions that determine bioavailability, mobility, and toxicity in soils (Rauret, 1998; Lock \& Janssen, 2001; Guo et al., 2006a). In soils with a mineralogy dominated by crystalline compounds and with lower organic matter content than volcanic soils, it has been found that a negligible movement of trace metals through the soil profile occurred after 17 years of sludge application (Sukkariyah et al., 2005), and Chang (Chang et al., 1984) found that $>90 \%$ of metals such as $\mathrm{Cd}, \mathrm{Cr}, \mathrm{Cu}, \mathrm{Ni}, \mathrm{Pb}$, and $\mathrm{Zn}$ added in that way remained in the surface layer $(0-0.15 \mathrm{~m})$ after 6 years. Unlike others contaminants, most metals do not undergo microbial or chemical degradation in the soil; therefore, metal concentrations will remain without significant changes for long periods of time (Guo et al., 2006b). 


\subsection{Impact on Soils from sewage sludge}

In Chile, the treatment works are gradually being brought online in recent years. Before that the collected wastewater was discharged directly and sewage sludge did not exist. With the start of wastewater treatment, sewage sludge and ash from the incinerated sewage sludge are accumulating in the metropolitan areas awaiting final disposal. On the other hand, the soils that would be most affected by these amendments are, of course, those that represent about $70 \%$ of the country's arable land, soils derived from volcanic ash. The predominant minerals of these soils are allophane and ferrihydrite in the andisols and kaolinite, halloysite and iron oxides in the ultisols. These soils are rich in iron oxides and organic matter, and they have $\mathrm{pH}$-dependent variable surface charge and high $\mathrm{PO}_{4}$ accumulation. However, the soils have poor fertility; at the original acidic $\mathrm{pH}$ range of 4.5 to 5.5 they have low capacity for exchangeable cations (CEC) and a strong selectivity for $\mathrm{K}$ and Ca over Mg (Escudey et al., 2004b). Phosphorus is strongly fixed by the minerals, and therefore it is not readily available for plant absorption in these soils. To be productive, they require frequent adjustments of $\mathrm{pH}$, replenishment of exchangeable $\mathrm{Mg}$, and heavy $\mathrm{PO}_{4}$ applications. When soil $\mathrm{pH}$ increases the CEC increases, $\mathrm{P}$ fixation decreases, and $\mathrm{K}$ selectivity is reduced. On the other hand, when the soil's organic matter increases, $\mathrm{K}$ selectivity is also reduced (Escudey et al., 2004b).

In relation to the impact of biosolids, either in their initial state or as ash, studies in pots and columns have been made on soils derived from volcanic materials. In this sense, forest fires are frequent in central-southern Chile; high temperatures may affect heavy metal $(\mathrm{Cu}, \mathrm{Zn}$, $\mathrm{Ni}, \mathrm{Pb}, \mathrm{Cd}, \mathrm{Mo}, \mathrm{Cr}$, and $\mathrm{Mn}$ ) chemical fractions naturally present in the soils and those coming from sewage sludge amendment. Changes in exchangeable, sorbed, organic, carbonate, and residual heavy metal fractions, evaluated by sequential extraction, were observed after heating at $400^{\circ} \mathrm{C}$ in two amended volcanic soils. The most significant heavy metals in these samples were $\mathrm{Cu}, \mathrm{Zn}, \mathrm{Pb}$, and $\mathrm{Ni}$. A significant increase in the total content of organic matter and metal ions such as $\mathrm{Zn}$ and $\mathrm{Cu}$ was observed in amended soils with respect to controls. In all samples, sorbed and exchangeable forms represent less than $10 \%$ of the total amount, while organic and carbonate fractions represent $24 \%$ and $48 \%$, respectively. The thermal treatment of amended soil samples results in a redistribution of the organic fraction, mainly into more insoluble carbonate and residual fractions such as oxides. Finally, the thermal impact is much more important in soils amended with sewage sludge if a heavy metal remediation process is considered, reducing the mobility and solubility of heavy metals supported by sewage sludge, minimizing leaching, and promoting accumulation in surface horizons (Antilen et al., 2006).

Column leaching experiments were conducted to test the ability of Chilean volcanic soils to retain the mineral constituents and metals in sewage sludge and sludge ash incorporated into the soils. Small or negligible amounts of the total content of $\mathrm{Pb}, \mathrm{Fe}, \mathrm{Cr}, \mathrm{Mn}, \mathrm{Cd}$, and $\mathrm{Zn}$ ( 0 to $<2 \%)$, and more significant amounts of mineral constituents such as $\mathrm{Na}$ (7 to $9 \%$ ), $\mathrm{Ca}(7$ to $13 \%), \mathrm{PO}_{4}$ (4 to $10 \%$ ), and $\mathrm{SO}_{4}$ (39 to $46 \%$ ) in the sludge and sludge ash were readily soluble. When they were incorporated on the surface layer of the soils and leached with 12 pore volumes of water over a 3 month period, less than $0.1 \%$ of the total amount of heavy metals and $\mathrm{PO}_{4}$ in the sludge and sludge ash were collected in the drainage water. Cation exchange selectivity, specific anion adsorption and solubility are the processes that cause the reduction of leaching. The volcanic soils were capable of retaining the mineral constituents, $\mathrm{P}$, and metals in applied sewage sludge and sludge ash and gradually released them as nutrients for plant growth. 


\subsection{Soil description and methods studied}

\subsubsection{Soils characterization}

Soil samples were collected in southern Chile from a depth of 0 to $25 \mathrm{cmin}$ the areas of Collipulli, Ralún, Diguillín, Metrenco, and Nueva Braunau, reflecting the localities from which the soils were extracted. The samples were obtained from well drained and regularly cultivated fields. Collipulli and Metrenco are classified as ultisols and Ralún, Diguillin, and Nueva Braunau as andisols. General information on the climate and geography of the soils is given in Table 4. Also, mineralogical composition can be observed in Table 5. The soil samples were screened in the field to pass a screen with $2 \mathrm{~mm}$ openings and stored at the field moisture content in a $4^{\circ} \mathrm{C}$ cold room until used.

\begin{tabular}{|c|c|c|c|c|c|c|c|}
\hline \multirow[t]{2}{*}{ Soil } & \multicolumn{2}{|c|}{ Location } & \multirow[t]{2}{*}{ Soil Order } & \multirow[t]{2}{*}{ Classification } & \multirow{2}{*}{$\begin{array}{l}\text { Altitude } \\
\text { (m) }\end{array}$} & \multirow{2}{*}{$\begin{array}{l}\text { Rainfall } \\
\left(\mathrm{m} \mathrm{yr}^{-1}\right)\end{array}$} & \multirow{2}{*}{$\begin{array}{c}\text { Annual } \\
\text { Mean } \\
\text { Temperature } \\
\left({ }^{\circ} \mathrm{C}\right)\end{array}$} \\
\hline & $\begin{array}{c}\text { Longitud } \\
\mathrm{e}\end{array}$ & Latitude & & & & & \\
\hline Collipulli (C) & $36^{\circ} 58^{\prime} \mathrm{S}$ & $72^{\circ} 09^{\prime} \mathrm{W}$ & Ultisol & Fine, mesic, Xeric, Paleumult & $120-400$ & $1.2-1.5$ & 15.8 \\
\hline Metrenco (M) & $38^{\circ} 34^{\prime} \mathrm{S}$ & $72^{\circ} 22^{\prime} \mathrm{W}$ & Ultisol & Fine, mesic, Paleumult & $100-300$ & $1.2-1.5$ & 14.6 \\
\hline Ralun (R) & $41^{\circ} 32^{\prime} \mathrm{S}$ & $73 \circ 05^{\prime} \mathrm{W}$ & Andisol & Mesic, Umbric Vitrandept & $600-1,400$ & $4.0-5.0$ & 10.5 \\
\hline Diguillin (D) & $36^{\circ} 53^{\prime} \mathrm{S}$ & $72^{\circ} 10^{\prime} \mathrm{W}$ & Andisol & Medial, thermic, Typic Dystrandept & $120-180$ & $1.2-1.8$ & 15.5 \\
\hline Nueva Braunau (NB) & $41^{\circ} 19^{\prime} \mathrm{S}$ & $7^{\circ} 06^{\prime} \mathrm{W}$ & Andisol & Ashy, mesic Hydric Dystrandept & $100-150$ & $1.2-1.5$ & 11.5 \\
\hline
\end{tabular}

Table 4. Soil classification information

\begin{tabular}{|l|c|c|c|c|c|}
\hline \multicolumn{1}{|c|}{ Mineral } & \multicolumn{1}{c|}{ C } & M & R & D & NB \\
\hline Allophane & & & +++++ & +++++ & +++++ \\
\hline$\alpha$-Cristobalite & + & & + & & + \\
\hline Chlorite - Al & & & ++ & & \\
\hline Feldspars & & & & & + \\
\hline Ferrihydrite & & & & + & + \\
\hline Gibbsite & & & & & ++ \\
\hline Geothite & & + & & & \\
\hline Halloysite & + & +++++ & & ++ & \\
\hline Kaolinite & +++++ & & & & \\
\hline Montmorillonite & & & + & & \\
\hline Organo-allophanic & & & & + & ++ \\
\hline Plagioclase & & & ++ & ++ & \\
\hline Quartz & & + & & & \\
\hline Vermiculite & + & & & + & \\
\hline
\end{tabular}

+++++ represents dominant $(>50 \%)$,

++++ represents abundant $(20-50 \%)$,

+++ represents common $(5-20 \%)$,

++ represents present $(1-5 \%)$, and

+ represents trace fraction $(<1 \%)$

Table 5. Mineralogical composition of soils as represented by the B horizon.

\subsubsection{Column experiments}

Soils were packed to a depth of $25 \mathrm{~cm}$ in $30 \mathrm{~cm}$ long and $10 \mathrm{~cm}$ diameter acrylic columns, according to their respective field bulk densities. A filter paper disk was placed on the perforated plate at the bottom of each column to prevent the loss of solid materials. The sewage sludge was obtained from a domestic water treatment plant located in Santiago (Chile) and the sewage sludge ash was obtained by heating the sewage sludge at $500^{\circ} \mathrm{C}$ for 
two hours. Depending on the treatment, $30 \mathrm{~g}$ of air-dried sewage sludge or the ash equivalent of 30 grams of air-dried sewage sludge were placed on the surface $5 \mathrm{~cm}$ of the packed columns. The experimental controls received no sludge or ash treatment. The columns, placed vertically, were flooded once a week with one pore volume of distilled water, and drained by gravity from top to bottom, for a period of 12 weeks. Furthermore, 30 $\mathrm{g}$ of sludge and the ash equivalent of $30 \mathrm{~g}$ of sludge were leached in the same manner. The drained liquid from each weekly leaching cycle was analyzed for $\mathrm{pH}$, electric conductivity, $\mathrm{SO}_{4}, \mathrm{PO}_{4}, \mathrm{Na}, \mathrm{K}, \mathrm{Mg}, \mathrm{Ca}, \mathrm{Zn}, \mathrm{Cu}, \mathrm{Fe}, \mathrm{Al}, \mathrm{Ni}, \mathrm{Cd}, \mathrm{Pb}, \mathrm{Mo}$, and $\mathrm{Mn}$.

At the end of the leaching experiment, each soil column was cut open lengthwise and the profile was sectioned into five equal length segments for analysis of the soils' $\mathrm{pH}$, electric conductivity, and organic carbon, exchangeable cation and $\mathrm{P}$ contents. A chemical fractionation of heavy metals was carried out in sludge and sludge ash using the methodology proposed by Chang (Chang et al., 1984). Sequential extraction with $0.5 \mathrm{M}$ $\mathrm{KNO}_{3}$, distilled water, $0.5 \mathrm{M} \mathrm{NaOH}, 0.05 \mathrm{M}$ EDTA, and $0.5 \mathrm{M} \mathrm{HNO}_{3}$ allowed the estimation of the exchangeable, sorbed, organic, carbonate, and residual heavy metal fractions.

\subsubsection{Chemical determinations}

The bulk density, exchangeable cations, total porosity, and organic carbon content of the soils were determined by methods outlined in Methods of Soil Analysis. Briefly, bulk density (Blake, 1965) was determined by the average air-dried weight of soils in undisturbed soil cores of the 0 to $25 \mathrm{~cm}$ soil profile in $5 \mathrm{~cm}$ (diameter) $\times 5 \mathrm{~cm}$ (height) brass rings; exchangeable cations were determined as the concentrations of $\mathrm{Na}, \mathrm{K}, \mathrm{Mg}$, and $\mathrm{Ca}$ in ammonium acetate extracts (Peech, 1965); and organic carbon was determined by the Walkley-Black method (Allison, 1965). The $\mathrm{pH}$ and electric conductivity of the soils were measured in soil suspensions with a1: $2.5 \mathrm{w} / \mathrm{v}$ soil-to-water ratio. The total elemental contents of $\mathrm{Na}, \mathrm{K}, \mathrm{Mg}, \mathrm{Ca}, \mathrm{Zn}, \mathrm{Cu}, \mathrm{Fe}, \mathrm{Al}, \mathrm{Ni}, \mathrm{Cd}, \mathrm{Pb}, \mathrm{Mo}, \mathrm{Mn}, \mathrm{P}$ and $\mathrm{S}$ were determined by digesting the soils with a concentrated $\mathrm{HNO}_{3}-\mathrm{HCl}-\mathrm{HF}$ mixture in a microwave oven and measuring the concentrations by ICP-OES spectroscopy (Perkin Elmer Optima 2000 equipment). Comparable components of the sewage sludge and sludge ash were determined in the same manner. The concentration of the same elements in leachates was also determined by ICP-OES; $\mathrm{SO}_{4}$ and $\mathrm{PO}_{4}$ concentrations in the drainage water were measured by ion chromatography (Waters 625LC) in a Waters IC Pak anion HR $4.5 \times 75 \mathrm{~mm}$ column. The absorbance of leachates was measured at 465 and $665 \mathrm{~nm}$ in a UV-Visible Perkin Elmer Lambda 20 spectrophotometer.

Prior to the sludge and ash treatments, the soils were acidic, with $\mathrm{pH}$ varying between 4.5 and 5.9, and low in exchangeable base contents varying from 1.5 to $10.4 \mathrm{cmol} \mathrm{kg}^{-1}$ (Table 6). In contrast, the sewage sludge and sludge ash had pH 7.7 and 7.4, respectively, 2 to 3 orders magnitude higher in alkalinity than the soils. The exchangeable base content of the sewage sludge was $80.6 \mathrm{cmol} \mathrm{kg}^{-1}, 10$ to 54 times higher than that of the soils. The $\mathrm{Na}, \mathrm{K}, \mathrm{Mg}$ and $\mathrm{Ca}$ in the sludge ash were soluble but not necessarily in the exchangeable forms. Judging from their electric conductivities, the soluble mineral contents of sewage sludge and sludge ash were orders of magnitude higher than those of the soils, even though the incineration of sewage sludge results in less soluble chemical forms, and consequently presents a lower electric conductivity than the sewage sludge. The total elemental $\mathrm{Ca}, \mathrm{Mg}$, $\mathrm{K}$, and $\mathrm{Na}$ content in the soils follows the same trends as that in the exchangeable forms and the concentrations are in the same order of magnitude. Column pore volume was calculated considering the amount of soil in the column and the total porosity of each soil (Table 6). 
Sewage Sludge Disposal and Applications: Self-heating and Spontaneous Combustion

\begin{tabular}{|c|c|c|c|c|c|c|c|c|c|}
\hline \multirow{2}{*}{ Soil } & \multirow{2}{*}{$\mathrm{pH}$} & \multirow{2}{*}{$\begin{array}{c}\text { Bulk } \\
\text { Density } \\
\left(\mathrm{g} \mathrm{cm}^{-3}\right)\end{array}$} & \multirow{2}{*}{$\begin{array}{c}\text { Pore } \\
\text { Volume } \\
(\mathrm{mL})\end{array}$} & \multirow{2}{*}{$\begin{array}{c}\text { Organic } \\
\text { Carbon } \\
(\%)\end{array}$} & \multirow{2}{*}{$\begin{array}{c}\text { Electrical } \\
\text { Conductivity } \\
\left(\mu \mathrm{S} \mathrm{m}^{-1}\right)\end{array}$} & \multicolumn{4}{|c|}{$\begin{array}{c}\text { Exchangeable Bases } \\
(\mathrm{cmol} \mathrm{kg}-1)\end{array}$} \\
\hline & & & & & & $\mathrm{Na}$ & K & $\mathrm{Mg}$ & $\mathrm{Ca}$ \\
\hline Collipulli (C) & 5.4 & 1.36 & 1027 & 2.3 & 81 & 0.1 & 0.2 & 1.8 & 5.9 \\
\hline Metrenco (M) & 5.5 & 1.33 & 1056 & 1.8 & 29 & 0.2 & 0.3 & 1.5 & 4.0 \\
\hline Ralún (R) & 4.5 & 0.90 & 988 & 6.2 & 436 & 0.1 & 0.1 & 0.4 & 2.5 \\
\hline Diguillin (D) & 5.9 & 1.12 & 830 & 6.5 & 94 & 0.2 & 0.7 & 1.1 & 8.4 \\
\hline N.Braunau (NB) & 5.5 & 0.82 & 834 & 11.0 & 20 & 0.1 & 0.1 & 0.2 & 1.1 \\
\hline Sludge & 7.7 & 0.46 & 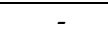 & 17.8 & 8520 & 1.5 & 2.5 & 10.7 & 65.9 \\
\hline Sludge Ash & 7.4 & - & - & $<0.1$ & 3890 & 1.2 & 1.1 & 7.4 & 25.8 \\
\hline
\end{tabular}

Table 6. Properties of soils, sewage sludge and sludge ash.

\subsubsection{Releases from sludge and sludge ash}

When the sludge and sludge ash were leached, soluble species such as $\mathrm{K}, \mathrm{Na}, \mathrm{Ca}$ and $\mathrm{Mg}$ appeared in the leachates. In general, the behavior observed for the $\mathrm{K}, \mathrm{Na}$ and $\mathrm{Mg}$ species indicates a gradual and constant elution, with an important removal in the first pore volume, considering that the curves describe the accumulated amount of exchangeable bases. Comparatively, Fig. 15 shows greater elution from the sludge than from the sludge
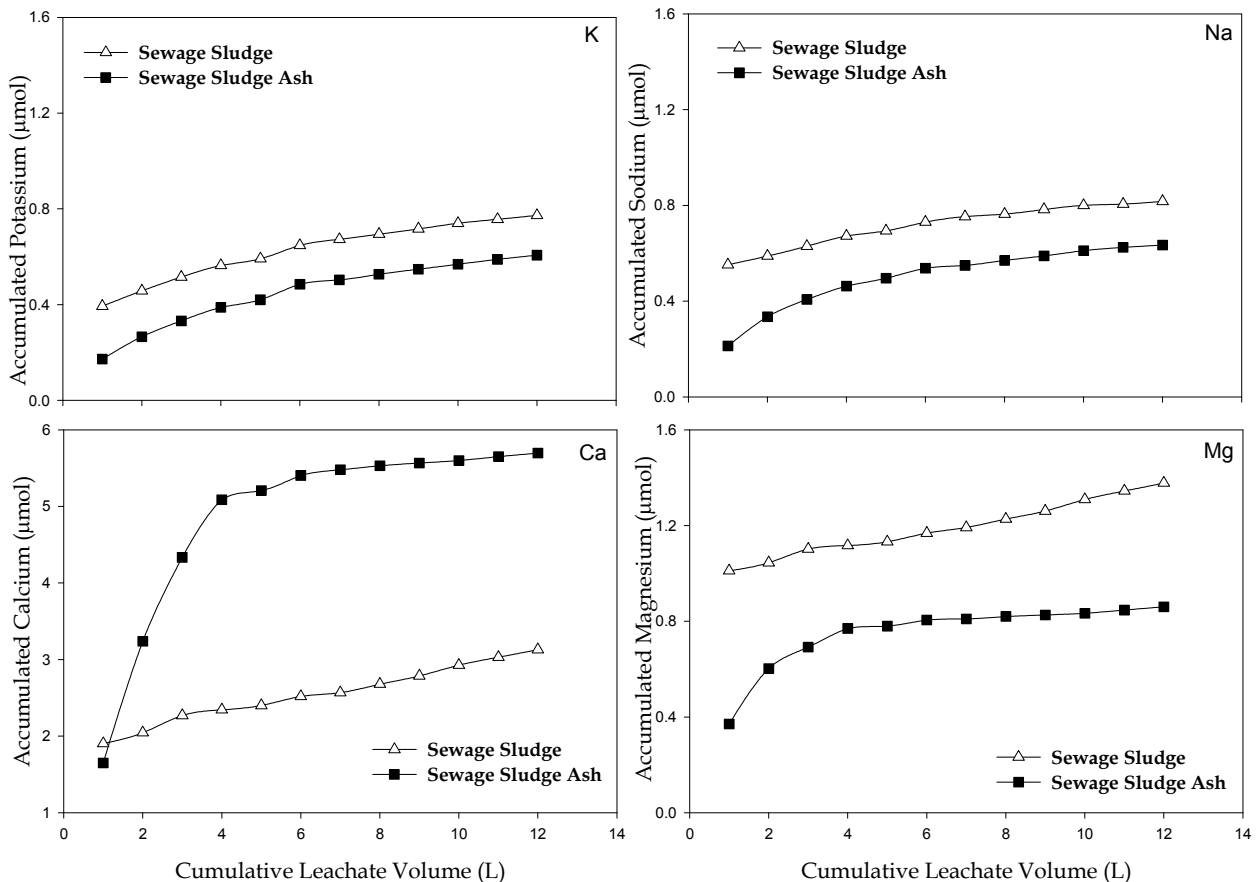

Fig. 15. Accumulated exchangeable bases ( $\mathrm{K}, \mathrm{Na}, \mathrm{Ca}$ and $\mathrm{Mg}$ ) from sewage sludge and sludge ash. 
ash, except for Ca. In that relation Ca also presents the greatest elution in the first four pore volumes, exceeding largely the elution from the sludge. This behavior is related to the addition of lime that is made in the water treatment plants with the purpose of stabilizing the $\mathrm{pH}$ of the residues. Another species of interest is sulfate, where the soluble $\mathrm{SO}_{4}$ in sewage sludge was depleted with one pore volume of water used to leach the soils. In contrast, the soluble $\mathrm{SO}_{4}$ in sewage sludge ash is gradually released with 5 to 8 pore volumes of water, with total amounts released of 342 and $319 \mathrm{mg}$, respectively.

One main domain is observed in sludge release which is associated to highly soluble forms. On the other hand, two main domains are observed in sewage ash, the first associated with soluble forms which are less important than in sludge, and a second from 2 to 5 pore volumes which can be associated with slow equilibrium between solid and water. In both samples the quantities released were a small fraction of the total amounts.

Only small amounts of $\mathrm{K}, \mathrm{Na}, \mathrm{Ca}, \mathrm{Mg}$ and $\mathrm{SO}_{4}$ were released when the sludge and sludge ash were subject to intense leaching for 12 weeks.

In Chile, the total metal content in the sewage sludge follows the sequence $\mathrm{Zn}>\mathrm{Cu}>\mathrm{Pb}>$ $\mathrm{Ni}$. Fractionation data show that $\mathrm{Zn}$ and $\mathrm{Cu}$ are mainly associated with highly insoluble fractions, such as carbonates and residual fraction. In control soils the total heavy metal content follows the sequence $\mathrm{Zn}>\mathrm{Cu}>\mathrm{Ni}>\mathrm{Pb}$ for Collipulli soil, and $\mathrm{Cu}>\mathrm{Zn}>\mathrm{Ni}>\mathrm{Pb}$ for Ralún soil (Antilen et al. 2006). On the other hand, the $\mathrm{Zn}$ and $\mathrm{Cu}$ release patterns for the sludge and sludge ash were similar (Figure 16), with the accumulated amounts released by the sludge considerably higher than those of the sludge ash.
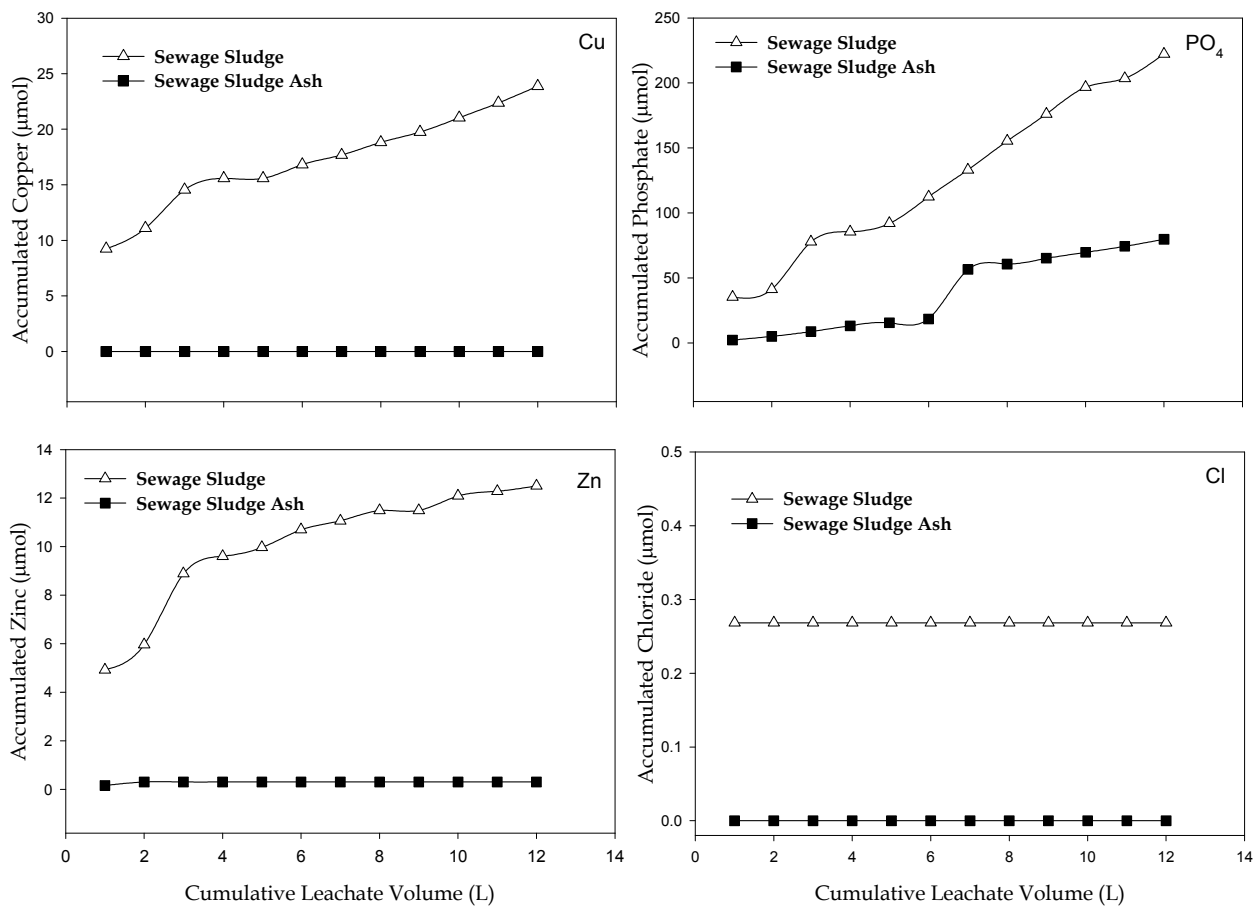

Fig. 16. Accumulated releases of heavy metals $(\mathrm{Cu}, \mathrm{Zn})$, phosphorus $\left(\mathrm{PO}_{4}\right)$ and chloride $(\mathrm{Cl})$. 
In relation to organic and inorganic $\mathrm{P}$ forms, both are present in sludge, while in sludge ash only inorganic $\mathrm{P}$ forms are present. The $\mathrm{P}$ forms in both samples are released slowly and at constant rates over time. In sludge, release is probably controlled by slow equilibrium between solid organic $\mathrm{P}$ forms and soil solution, and by the solubility of inorganic $\mathrm{P}$ forms. Consequently, at the end of 12 leaching cycles, small amounts of $\mathrm{PO}_{4}$ were recovered from the drainage liquids of sewage sludge and sludge ash (18 and $6 \mathrm{mg}$, respectively) compared with their total contents (181 and $170 \mathrm{mg}$, respectively).

Even though $\mathrm{Cu}$ and $\mathrm{Zn}$ are the main heavy metals in Chilean sewage sludge, other heavy metals of environmental interest, such as $\mathrm{Ni}, \mathrm{Cd}, \mathrm{Cr}$, Mo and $\mathrm{Mn}$, were also considered. The total eluted amounts of some of these metals are shown in Table 7, where it is clear that it is minimal compared to the content in the sludge.

\begin{tabular}{|c|c|c|c|c|c|c|c|}
\hline & \multicolumn{7}{|c|}{ Total leached amount } \\
& \multicolumn{7}{|c|}{$(\mu \mathrm{mol})$} \\
\hline & $\mathrm{Cr}$ & $\mathrm{Ni}$ & $\mathrm{Mo}$ & $\mathrm{Mn}$ & $\mathrm{Cd}$ & $\mathrm{Cu}$ & $\mathrm{Zn}$ \\
\hline Sewage sludge & 1.00 & 6.07 & 1.61 & 9.15 & 0.00 & 0.00 & 0.789 \\
\hline Sewage sludge ash & 0.32 & 0.11 & 2.47 & 1.86 & 0.00 & 1.61 & 0.02 \\
\hline
\end{tabular}

Table 7. Accumulated heavy metals leached with12 pore volumes from sewage sludge and sludge ash

\subsubsection{Soil attenuation}

The $\mathrm{pH}$ of leachates in the control and treated soils increases after 12 pore volumes; the final $\mathrm{pH}$ is about 1.5 to 2.0 units higher than the initial $\mathrm{pH}$. The process is controlled by the soil; thus, after 12 pore volumes the $\mathrm{pH}$ of treated soil leachates is only about $0.3 \mathrm{pH}$ units higher than those observed in the control columns. In all the experiments, after 12 pore volumes, the leachate $\mathrm{pH}$ is basic, ranging from 7 to 8 .

The leaching of organic matter was followed by measuring the absorbance of the leachates after each pore volume at 465 and $665 \mathrm{~nm}$. Only leachates from Ralún soil columns showed absorbance higher than zero, but the amount of organic matter leached was too low to be quantified. No significant loss of organic colloids was observed, because the mass balance shows that the organic carbon remains constant in all columns considering the experimental errors of the Walkley-Black method.

Even without the applications of sludge or sludge ash, cations and anions such as $\mathrm{Mg}$, and $\mathrm{SO}_{4}$ may be leached from the soils (Figure 17) and the amounts collected in the drainage water were dependent on the conditions of the soils. Sludge and sludge ash amendments consistently enhanced the leaching of minerals. However, the collected amounts were significantly smaller than the total introduced through the addition of sludge or sludge ash, and are practically leached in the first 3 or 4 pore volumes of drainage water.

Soil incorporation further reduced the mobility of the chemical constituents in the sludge and sludge ash (Figure 18). For P, the amounts found in the drainage water (Figure 18) were 2 to 3 orders of magnitude lower than the amounts present in the added sludge and sludge ash.

As a result, nutrients such as available $\mathrm{P}$ significantly increased with the application of sewage sludge and sludge ash for both the Ultisol and Andisol (Figure 19). The general trend in all the experiments was that only a small fraction of the total amounts incorporated by the addition of sludge or sludge ash were leached. 


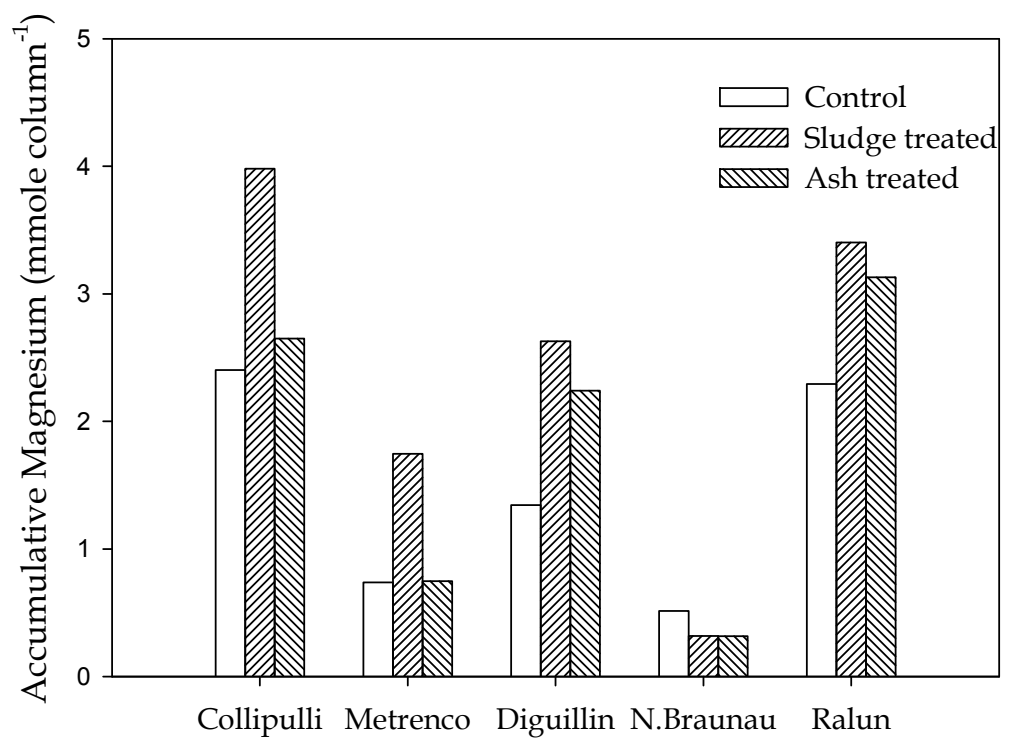

(A)

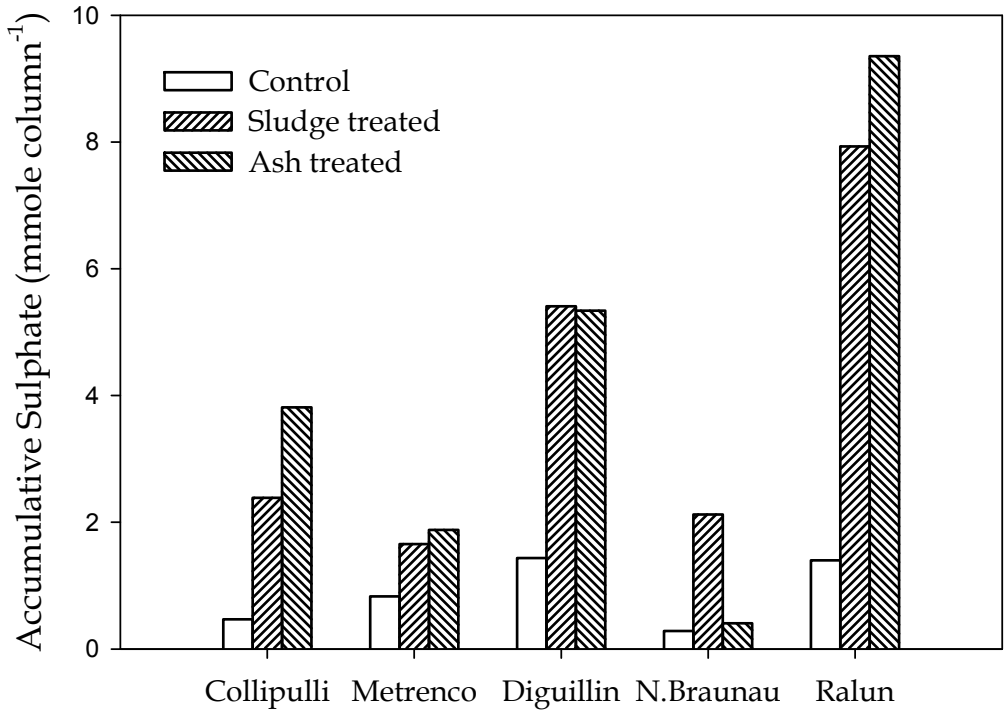

(B)

Fig. 17. Total amount of $\mathrm{Mg}(\mathrm{A})$ and $\mathrm{SO}_{4}$ (B) leached from sewage sludge and sludge ash treated soils. 


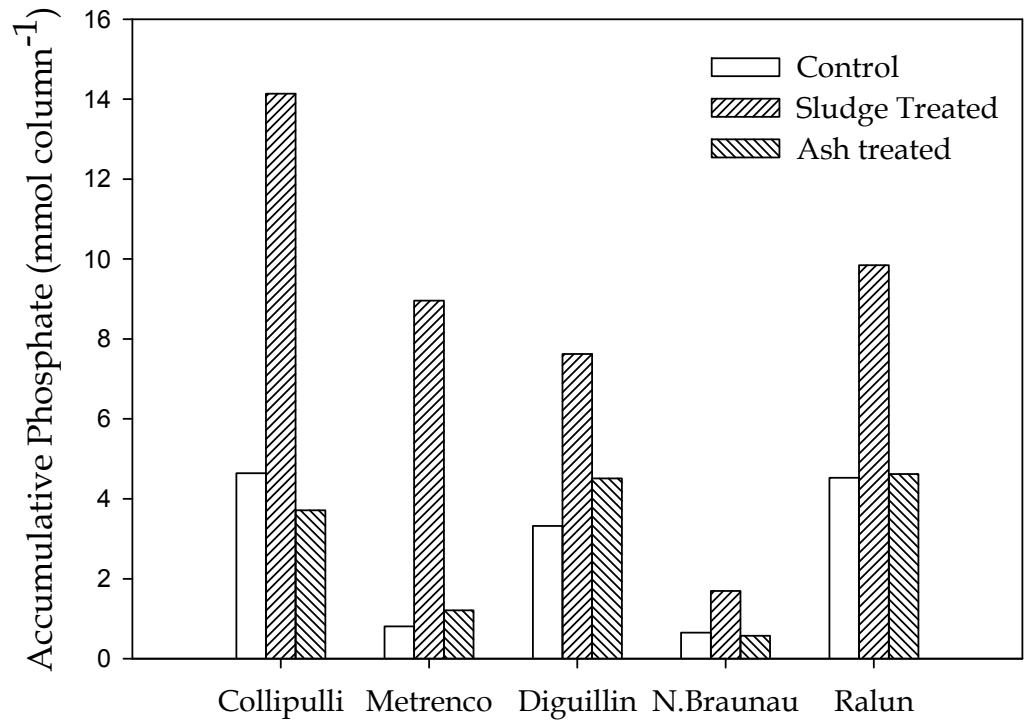

Fig. 18. Total amount of $\mathrm{PO}_{4}$ leached from sewage sludge and sludge ash treated soils.

As an example, the total input from sludge and ash, the total amount leached from them, and the total amount collected after 12 pore volumes for the Collipulli and Nueva Braunau soils, are presented in Figure 20. The total amount of heavy metals $(\mathrm{Cu}, \mathrm{Zn}, \mathrm{Ni}, \mathrm{Cd}, \mathrm{Pb}, \mathrm{Mo}$, $\mathrm{Mn}$ ) leached after 12 pore volumes was $<0.1 \%$ of the total input from sewage sludge or sewage ash (represented by $\mathrm{Zn}, \mathrm{Cu}$ and $\mathrm{Pb}$ in Figure 20). On the other hand, the leached fractions of $\mathrm{SO}_{4}$ (22 to $\left.55 \%\right), \mathrm{Na}(7$ to $15 \%), \mathrm{K}(2$ to $30 \%), \mathrm{Ca}(3$ to $7 \%)$, and $\mathrm{Mg}$ (2 to $30 \%$ ) are more significant.

The leaching of exchangeable bases behaves as predicted by previously reported cation exchange selectivity (Escudey et al. 2002). Phosphate is leached in very low amounts $(<0.1 \%)$, even though sewage sludge and sludge ash present high $\mathrm{P}$ content; this is due to the specific $\mathrm{PO}_{4}$ adsorption which is a characteristic of Chilean volcanic soils (Escudey et al. 2001).

Fractionation experiments show that 86 to $99 \%$ of heavy metal chemical forms in sewage sludge are associated with organic matter complexes, carbonate, and residual low solubility compounds, and that 95 to $99 \%$ is associated with carbonate and low solubility forms in sludge ash. All of them have low mobility, and consequently their leaching is mainly associated to the more soluble chemical forms, which are present only in very low concentration in both substrates. 

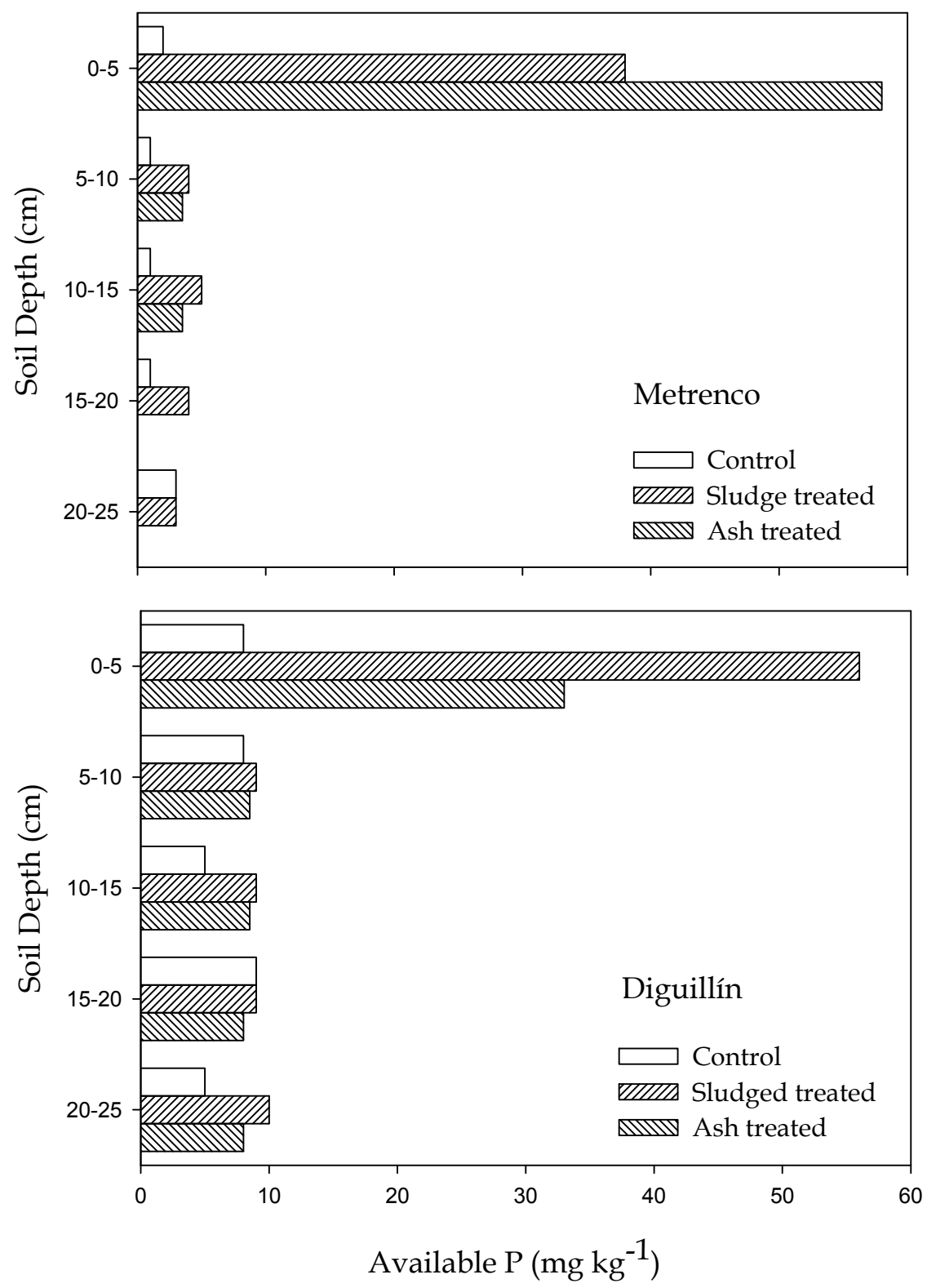

Fig. 19. Available P in the sewage sludge and sludge ash treated ultisol (Metrenco) and andisol (Diguillin). 

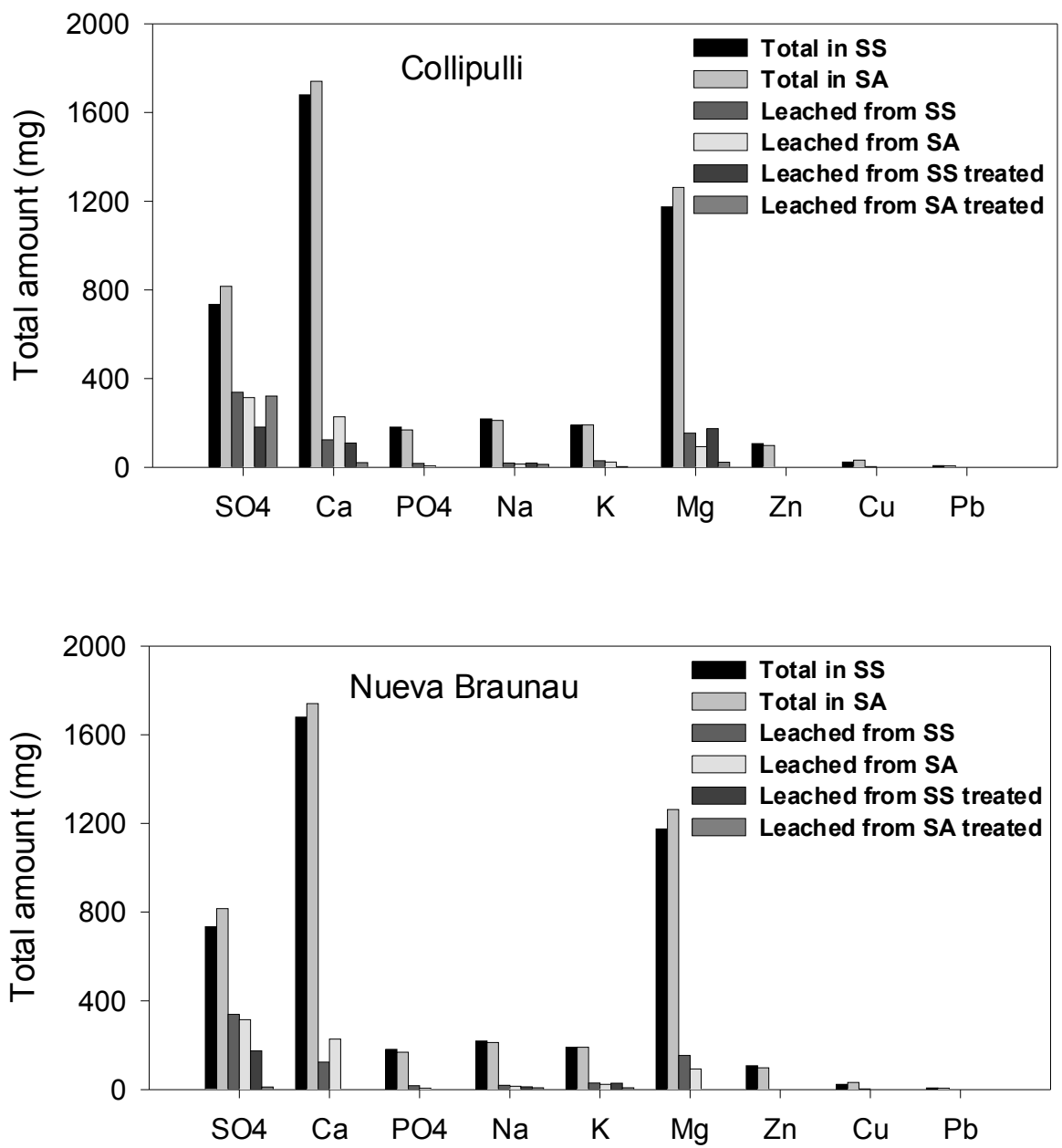

Fig. 20. Total amount of selected cations and anions in sewage sludge and equivalent ash (Total in SS, SA), total amount leached from sewage sludge and sewage ash (Leached from SS, SA), and leached from sewage sludge-treated columns and ash-treated columns (Leached from SS treated, ash treated), for Collipulli and Nueva Braunau soils.

\subsection{Conclusions}

Results of column leaching experiments showed that volcanic soils in Chile were capable of retaining the inorganic mineral constituents, $\mathrm{P}$, and $\mathrm{Zn}$ in sewage sludge and sludge ash when land applied. These constituents are essential inputs to enhance the productivity of volcanic soils that are frequently low in fertility. Cation exchange selectivity, specific anion adsorption and solubility are the processes that cause the reduction of leaching. In this regard, the volcanic soils will attenuate the sewage sludge-borne pollutants and provide soils with nutrients that may be slowly released for crop production. 


\section{References}

Allison, L. E. (1965). Organic carbon In: Methods of Soil Analysis. Part 2 Agronomy 9, Black, C.A.; Evans, D.D.; White, J. L.; Ensminger, L.E. \& Clark, F.E. (Eds.),1367-1396, American Society of Agronomy, Madison, WI.

Antilen, M.; Araya, N.; Briceño,M.; Escudey, M (2006) Changes on chemical fractions of heavy metals in Chilean soils amended with sewage sludge affected by a thermal impact. Australian Journal of Soil Research 44, 1-7, 0004-9573.

Bastian, R. K. (1997). Biosolids management in the United States, A state-of-the-nation review. Water Environmental Technology, 9, 45 - 50, 1044-9493.

Blake, G.R. (1965). Bulk density, In: Methods of Soil Analysis. Part 1 Agronomy 9, Black, C.A.; Evans, D.D.; White, J. L.; Ensminger, L.E. \& Clark, F.E. (Eds.), 1367-1396, American Society of Agronomy, ISBN, Madison, WI.

Bonnin, C. (2001). Organic pollutants and sludge - The French experience. Research The Sludge Directive, Proceedings of a Conference on Sewage Sludge, Belgian, October, 2001, Brussels.

Chang, A.C.;. Warneke, J.E.; Page, A.L.\& Lund L. J. (1984). Accumulation of heavy metals in sewage sludge-treated soils. Journal of Environmental Quality, 13, 87-91, 0047-2425.

Chen, X.D. \& Mitchell, D.A. (1996). Star-up strategize of self-heating and efficient growth in stirred bioreactor for solid state bioreactors, Proceedings of the 24th Annual Australian and New Zealand Chemical Engineering Conference (CHEMECA 96), 111-116.

Duffie, J.A. \& Beckman, W.A. (1980). Solar Engineering of Thermal Processes, John Wiley \& Sons, New York, 1980.

Eriksson, J.(1998). Dissolution of hardened wood ashes in forest soils: studies in a column experiment, Scandinavian. Journal of Forest Research , 2, 23-32, 1341-6979.

Escudey M, Galindo G, Avendaño K, Borchardt D, Chang A, Briceño M (2004a) Distribution of phosphorus forms in Chilean soils and sewage sludge by chemical fractionation and 31P-NMR. Journal of Chilean Chemical Society 49, 219-222, 0717-9707.

Escudey M, Forster JE, Galindo G (2004b) Relevance of organic matter in some chemical and physical characteristics of volcanic ashderived soils in Chile. Communications in Soil Science and Plant Analysis 35, 781-797, 1532-2416.

Escudey M.; Arias, A.; Förster, J.; Moraga, N.; Zambra, C. \& Chang, A. C. (2008). Sewage sludge self-heating and spontaneous combustion. field, Laboratory and numerical studies; High Temperature Material and Processes 27(5).

Escudey, M.; Diaz, P.; Förster, J.E.; Pizarro, C.; Beltrán, L. \& Galindo, G.(2002). Prediction of $\mathrm{K}-\mathrm{Ca}-\mathrm{Mg}$ ternary exchange from binary isotherms in volcanic soils using the Rothmund-Kornfeld approach. Australian Journal of Soil Research, 40, 781790,0004-9573.

Escudey, M.; Galindo, G.;. Förster, J. E.; Briceño, M.; Díaz, P.; Chang, A. C. (2001). Chemical forms of phosphorus of volcanic ash-derived soils in Chile, Communication in Soil Science and Plant Analysis, 32, 601-616, 1532-2416.

Geankoplis, C.J. (1993). Transport processes and unit operations, Prentice-Hall International Inc. USA.

Guo G, Zhou Q, Koval P, Belogolova G (2006a) Speciation distribution of Cd, Pb, Cu, and Zn in contaminated Phaeozem in north-east China using single and sequential extraction procedures. Australian Journal of Soil Research 44, 135-142, 0004-9573. 
Guo G, Zhou Q. Lena M (2006b) Availability and assessment of fixing additives for the in situ remediation of heavy metal contam United soils: a review. Environmental Monitoring and Assessment 116, 513-528, 0167-6369.

http://europa.eu.int/comm/environment/sludge.

Illera, V.; Walter, I.; Souza, P. \& Cala, V. (2000). Short-term effects of biosolid and municipal solid waste applications on heavy metals distribution in a degraded soil under a semi-arid environment. Science of the Total Environment, 255, 29-44, 0048-9697.

Kaya, A.; Aydin, O. \& Dincer, I. (2006). Numerical modeling of heat and mass transfer during forced convection drying of rectangular moist objects, International Journal of Heat andMass Transfer 49, 3094-3103.

Lock K, Janssen C (2001) Cadmium toxicity for terrestrial invertebrates: taking soil parameters affecting bioavailability into account. Ecotoxicology 10, 315-322, 09639292.

Margherita E, Brunetti G, Garcia-Izquierdo C, Covalcante F, Fiore S, Senesi N (2006) Humic substances and clay minerals in organically-amended semiarid soils. Soil Science 171, 322-333, 0038-075X.

Moraga, N.; Corvalán, F.; Escudey, M.; Arias, A. \& Zambra, C. (2009). Unsteady 2D coupled heat and mass transfer diffusion in porous media with biological and chemical heat generations; International Journal of Heat and Mass Transfer 52; 5841-5848.

Nield, D. \& Bejan, A. (1992). Convection in Porous Media, Springer-Verlag, New York.

Ozisik, M.N. (1994). Finite difference methods in heat transfer, CRC Press Inc., USA.

Pasquini, M.W. \& Alexander, M.J.(2004). Chemical properties of urban waste ash produced by open burinig on the Jos Plateau: implications for agriculture. Science of the Total Environment, 319, 225-240, 0048-9697.

Patankar, S.V. (1991). Computation of Conduction and Duct flow Heat Transfer, Innovative Research, Inc., Maple Grove, Minnesota.

Peech, M. (1965). Exchange acidity In: Methods of Soil Analysis. Part 1 Agronomy 9, Black, C.A.; Evans, D.D.; White, J. L.; Ensminger, L.E. \& Clark, F.E. (Eds.), 905-913, American Society of Agronomy, Madison, WI..

Rauret G (1998) Extraction procedures for the determination of heavy metals in contaminated soils and sediment. Talanta 46, 449-455, 0039-9140.

Richards, L.A. (1931). Capillary conduction of liquids through porous mediums, Physics 1, 318-333.

Serrano, S. (2004). Modeling infiltration with approximated solution to Richards equation, Journal of Hydrologic Engineering 9(5), 421-432.

Sidhu, H.S.; Nelson, M.I. \& Chen, X.D. (2007). A simple spatial model for self-heating compost piles, ANZIAM J. (CTAC2006) 41, C135-C150.

Sukkariyah B, Evanylo G, Zelazny L, Chaney R (2005) Recovery and distribution of biosolids-derived trace metals in a clay loam soil. Journal of Environmental Quality 34, 1843-1850, 0047-2425.

Walkley, A. \& Black, L.A. (1934). An examination of the Degtjareff method for determining soil organic matter and a proposed modification of the chromic acid titration method. Soil Science 37, 29-38.

Walter, I. \& Cuevas, G. (1999). Chemical fractionation of heavy metals in a soil amended with repeated sewage sludge application. Science of the Total Environment, 226, 113 119, 0048-9697. 
Zhang, F.; Yamasaki, S.; Nanzyo, M. (2002a). Waste ashes for use in agricultural production: I. Liming effect, contents of plant nutrients and chemical characteristics of some metals. Science of the Total Environment, 284, 215-225, 0048-9697.

Zhang, F.; Yamasaki, S.; Nanzyo, M. (2002b). Waste ashes for use in agricultural production: II. Contents of minor and trace metals. Science of the Total Environment, 286, 111-118, 0048-9697. 


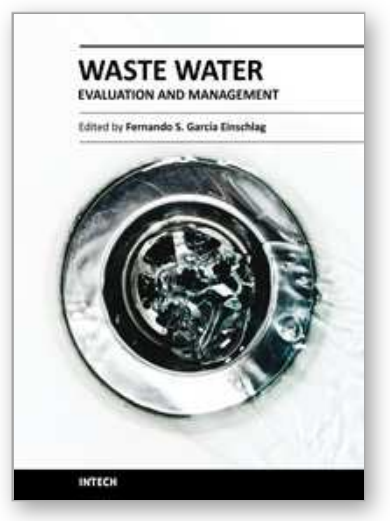

\author{
Waste Water - Evaluation and Management \\ Edited by Prof. Fernando Sebastĩ̃̃in GarcÃa Einschlag
}

ISBN 978-953-307-233-3

Hard cover, 470 pages

Publisher InTech

Published online 01, April, 2011

Published in print edition April, 2011

Fresh water resources are under serious stress throughout the globe. Water supply and water quality degradation are global concerns. Many natural water bodies receive a varied range of waste water from point and/or non point sources. Hence, there is an increasing need for better tools to asses the effects of pollution sources and prevent the contamination of aquatic ecosystems. The book covers a wide spectrum of issues related to waste water monitoring, the evaluation of waste water effect on different natural environments and the management of water resources.

\title{
How to reference
}

In order to correctly reference this scholarly work, feel free to copy and paste the following:

Mauricio Escudey, Nelson Moraga, Carlos Zambra and Mónica Antilén (2011). Sewage Sludge Disposal and Applications: Self-heating and Spontaneous Combustion of Compost Piles - Trace Metals Leaching in Volcanic Soils After Sewage Sludge Disposal, Waste Water - Evaluation and Management, Prof. Fernando SebastiÃ $i n$ GarcÃa Einschlag (Ed.), ISBN: 978-953-307-233-3, InTech, Available from:

http://www.intechopen.com/books/waste-water-evaluation-and-management/sewage-sludge-disposal-andapplications-self-heating-and-spontaneous-combustion-of-compost-piles-tra

\section{INTECH}

open science | open minds

\section{InTech Europe}

University Campus STeP Ri

Slavka Krautzeka 83/A

51000 Rijeka, Croatia

Phone: +385 (51) 770447

Fax: +385 (51) 686166

www.intechopen.com

\section{InTech China}

Unit 405, Office Block, Hotel Equatorial Shanghai

No.65, Yan An Road (West), Shanghai, 200040, China 中国上海市延安西路65号上海国际贵都大饭店办公楼 405 单元

Phone: +86-21-62489820

Fax: +86-21-62489821 
(C) 2011 The Author(s). Licensee IntechOpen. This chapter is distributed under the terms of the Creative Commons Attribution-NonCommercialShareAlike-3.0 License, which permits use, distribution and reproduction for non-commercial purposes, provided the original is properly cited and derivative works building on this content are distributed under the same license. 